\title{
Il disegno per l'infanzia: approcci interdisciplinari per una nuova forma di didattica
}

\author{
Alessio Cardaci
}

\section{Abstract}

L'insegnamento del Disegno all'interno dei corsi di laurea in Scienze della Formazione Primaria sollecita nuove riflessioni del nostro settore volte a una rimodulazione della didattica non più rivolta alla formazione di ingegneri e architetti ma di educatori. Figure professionali che dovranno impiegare lo strumento grafico non per la comprensione e la valorizzazione dell'architettura e del paesaggio ma come strumento fondamentale per la comunicazione dello spazio interiore del bambino. Una concezione allargata della disciplina, priva di un legame diretto con la rappresentazione del patrimonio architettonico e naturale, incardinata su una stretta relazione con le arti visive insieme alle dottrine di storia dell'arte e scienze sociali. Su queste basi si è progettato, presso l'Università di Bergamo, un insegnamento particolare - forse sperimentale - che ha affidato al Disegno il ruolo, sia di correlazione tra l'educazione artistica e quella musicale, sia di membrana permeante di relazione con le discipline psicologiche e pedagogiche.

Parole chiave

cooperative learning, arte e musica, scuola primaria, pedagogia, psicologia, Bergamo.

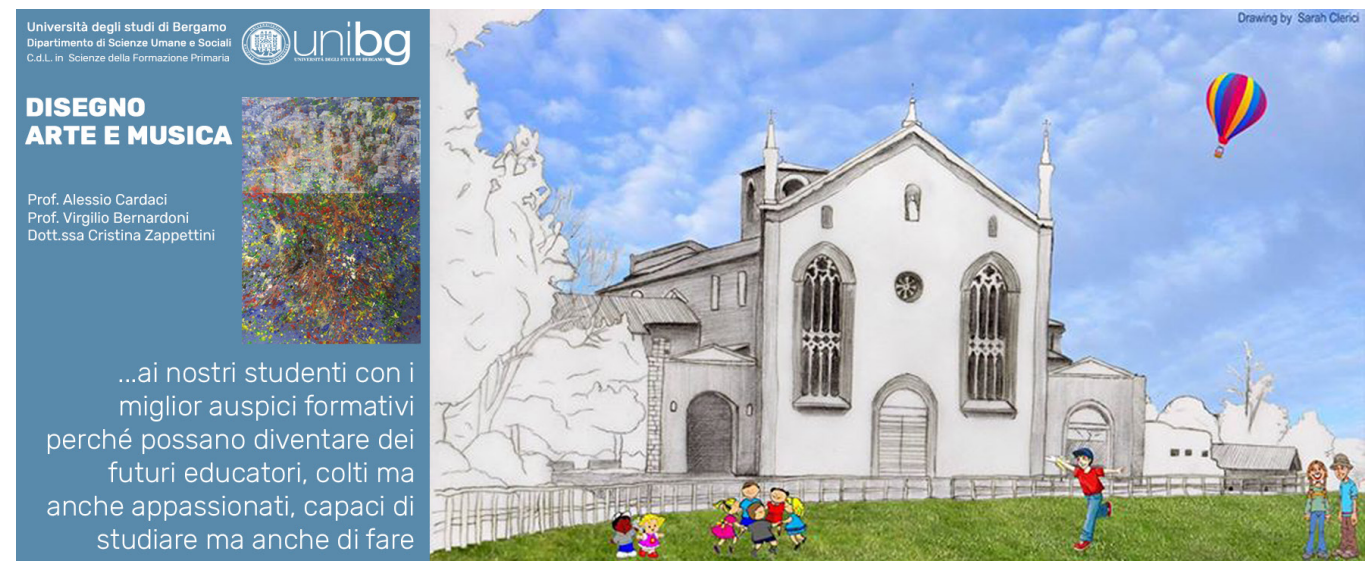




\section{II ruolo del disegno in Scienze della Formazione Primaria}

Il percorso formativo in Scienze della Formazione Primaria prepara a diventare insegnanti della scuola d'infanzia ed elementare. Un corso di laurea a ciclo unico di cinque anni e numero programmato, finalizzato a favorire l'inserimento lavorativo attraverso un titolo di studio abilitante alla professione. Un'offerta rivolta sia a giovani studenti diplomati, sia ai 'vecchi maestri' e agli educatori degli asili d'infanzia che desiderano acquisire la laurea per un miglioramento professionale e della propria posizione lavorativa. II corso in Scienze della Formazione Primaria, più che un ciclo di studio "è una vera e propria comunità di apprendimento" fondata su una forte interdisciplinarità e una stretta interrelazione con il mondo della scuola. II ruolo dell'insegnante della primaria è di avviare il bambino all'apprendimento e stimolare in lui la curiosità verso la conoscenza; un processo finalizzato a favorire l'alfabetizzazione culturale, basato sul piacere della scoperta e della propria individualità. L'insegnante della scuola primaria deve infatti concorrere, insieme alla famiglia, durante la scuola materna "allo sviluppo affettivo, psicomotorio, cognitivo, morale, religioso e sociale delle bambine e dei bambini" e, durante il primo ciclo dell'istruzione "favorire la socializzazione e l'acquisizione delle prime conoscenze e delle abilità di base" (D.L. 59, 2004). Lo sviluppo cognitivo e psicologico, nonché delle capacità logico-relazionali, devono avvenire grazie a un'attività ludico-educativa che incentivi la creatività, il pensiero autonomo e le relazioni sociali. Un percorso in cui la trasmissione della conoscenza della singola disciplina assume una funzione secondaria all'interno di un dialogo ampio e interdisciplinare.

I piani degli studi offerti dalle varie sedi universitarie, non molto dissimili tra loro in ragione dell'ordinamento nazionale, ne sono la palese dimostrazione; essi sono improntati su insegnamenti di base in ambito pedagogico completati da un vastissimo numero di materie caratterizzanti. L'insegnamento del Disegno (SSD Icar/17) è compreso all'interno delle 'Discipline delle Arti', insieme alle dottrine di storia dell'arte moderna e contemporanea, nonché allo studio e alla narrazione per immagine di cinema, fotografia e televisione. Una concezione del Disegno allargata, priva di un legame diretto con la rappresentazione della realtà costruita e del contesto territoriale e paesistico, incardinata su una stretta relazioni con le arti visive e finalizzata all'educazione all'immagine attraverso la conoscenza degli strumenti e delle tecniche di rappresentazione nelle diverse aree artistiche.

Questo domanda un serio impegno del nostro settore ai fini di una riflessione e rimodulazione della didattica, non più rivolta alla formazione di ingegneri e architetti ma di educatori; figure professionali che dovranno utilizzare il Disegno non per la comprensione e la valorizzazione dell'architettura, dell'ambiente antropico e naturale, ma servirsene quale strumento fondamentale per la comunicazione dello spazio interiore del bambino. Su queste basi si è progettato, presso l'Università di Bergamo, un insegnamento particolare

Fig. I. La struttura didattica della lezione: gli studenti sono impegnati fsicamente nelle attività correndo, cammina bendati, fermandosi improvisamente per commentare a gruppi le diapositive.
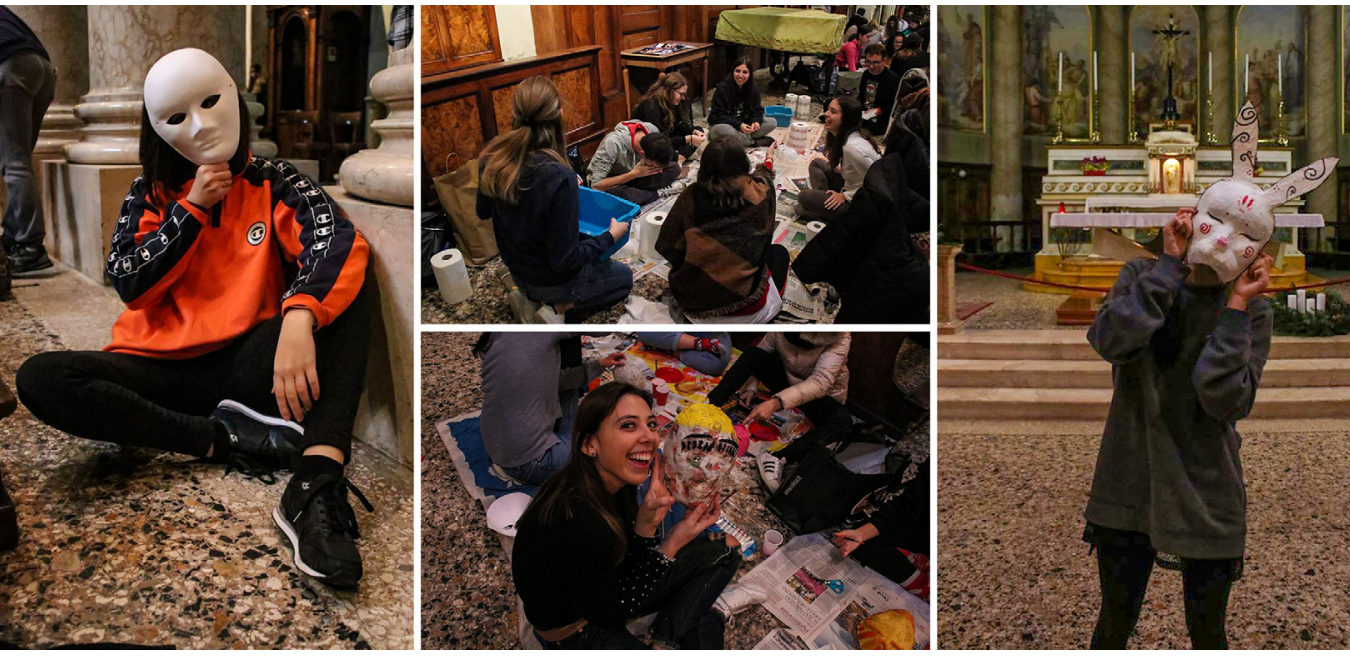
- forse sperimentale - che ha affidato al Disegno il ruolo, sia di correlazione tra l'educazione artistica e quella musicale, sia di membrana permeante di relazione con le discipline psicologiche e pedagogiche.

\section{C.I di Disegno Arte e Musica}

Premesse didattiche: II C.I di Disegno, Arte e Musica attivo presso l'Università degli Studi di Bergamo è un insegnamento nato dall'integrazione di competenze tra i settori della pedagogia, della psicologia e della scienza della rappresentazione. Il corso si propone di avvicinare gli allievi alla percezione e alla comunicazione visiva, di educarli alla lettura delle immagini, di stimolarli all'utilizzo della tecnica grafica quale mezzo espressivo di comunicazione emotiva. Una visione del Disegno che intende riattribuire al sostantivo il significato "DI sé il SEGNO", relazionando le attività all'individuo che utilizza forme e colori per esprimere il proprio mondo interiore.

Ecco, quindi, la progettazione di una serie di attività che hanno come elemento comune l'avvicinare e, si auspica, il far appassionare gli studenti al Disegno e alla comunicazione grafica. È infatti necessario che i nuovi insegnanti si innamorino della disciplina per poterla comunicare ai bambini e, successivamente, avvicinarli all'atto grafico come gesto naturale e spontaneo dettato dal coinvolgimento e dalla necessità di comunicare il proprio $I O$ più recondito e profondo.

La didattica vuole trasmettere lo spirito della dottrina ma, soprattutto, far comprendere ai futuri 'maestri' che è possibile manifestare il proprio infinito sia attraverso la manualità del disegno libero, sia tramite la conoscenza e l'utilizzo degli strumenti atti alla figurazione (tradizionali e digitali). La scienza della rappresentazione non è la semplice istruzione alle conoscenze legate alla tecnica e alla metodologia della rappresentazione, ma la materializzazione di un pensiero che si manifesta attraverso il segno grafico.

Questo si ottiene grazie ai workshop e alle attività laboratoriali che si pongono l'obiettivo di ricondurre gli studenti a essere infanti; retrocedere allo stato infantile per avvicinarsi nuovamente al disegno espressivo e compositivo. Solo se in questo percorso si appassioneranno a ciò che stanno realizzando potranno, un domani, guidare i bimbi - con lo stesso amore e il medesimo trasporto - sulla stessa strada che li ha visti protagonisti nella loro vita accademica. Le lezioni, durante lo svolgimento, devono 'far regredire' la classe allo stato infantile, per affrontare le esercitazioni assegnate; gli studenti sono quindi attori che si devono imme-

Fig. 2. La struttura

didattica della lezione: gli studenti vengono coinvolti in attività di gruppo per svolgere i laboratori; si adattano allo spazio attorno a loro lavorando sul pavimento, nei corridoi, sulle vetrate.

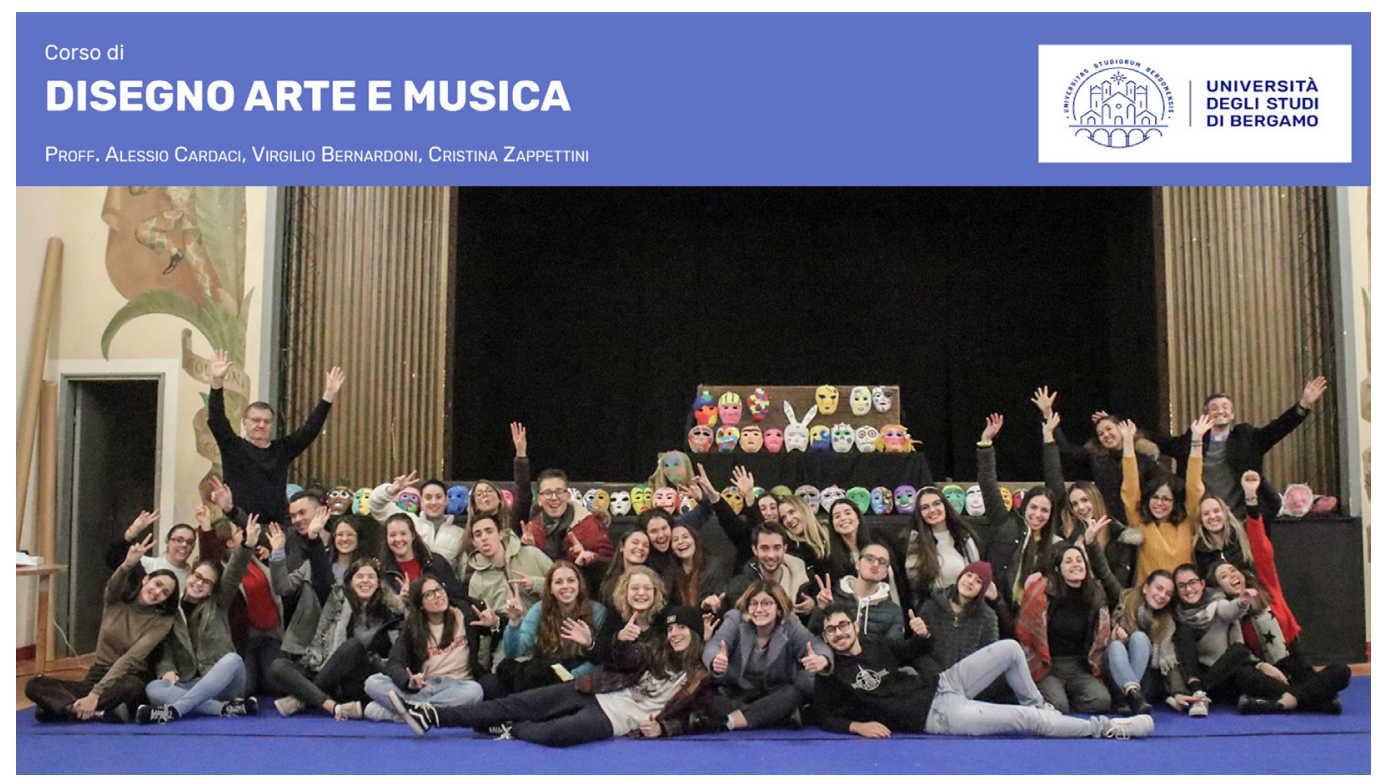


desimare e recitare - con incoscienza e inconsapevolezza - il ruolo degli scolari della scuola dell'infanzia e delle elementari.

I laboratori sono imperniati su due temi principali: il Disegno emozionale e il Disegno per la costruzione dell'immagine. Le esercitazioni legate al Disegno emozionale (ad esempio le texture, lab-Pollock, 3D puzzle, io e la mia maschera, ...) sono principalmente indirizzate al percorso prescolastico rivolto ai bambini dai 2 ai 6 anni di età, come parte integrante di un preciso progetto educativo interdisciplinare. Lo scopo delle esercitazioni riferite al Disegno per la costruzione dell'immagine (come il photo-collage, la composizione di fumetti, il ridisegno delle immagini, Il disegno condiviso, ...), invece, è la creazione di un'immagine complessa, composizione di immagini più semplici; esse sono dunque pensate per la formazione primaria in cui i bambini, della fascia di età dai 7 ai 12 anni, hanno già acquisito la necessaria tecnica grafica e la capacità nell'uso degli strumenti della rappresentazione.

Fig. 3. La struttura didattica della lezione: il lab-Pollack aperto alla partecipazione dei bambini; gli studenti coibambini,g studenti svolgonole estertazioni e - a volte - i propri figli.
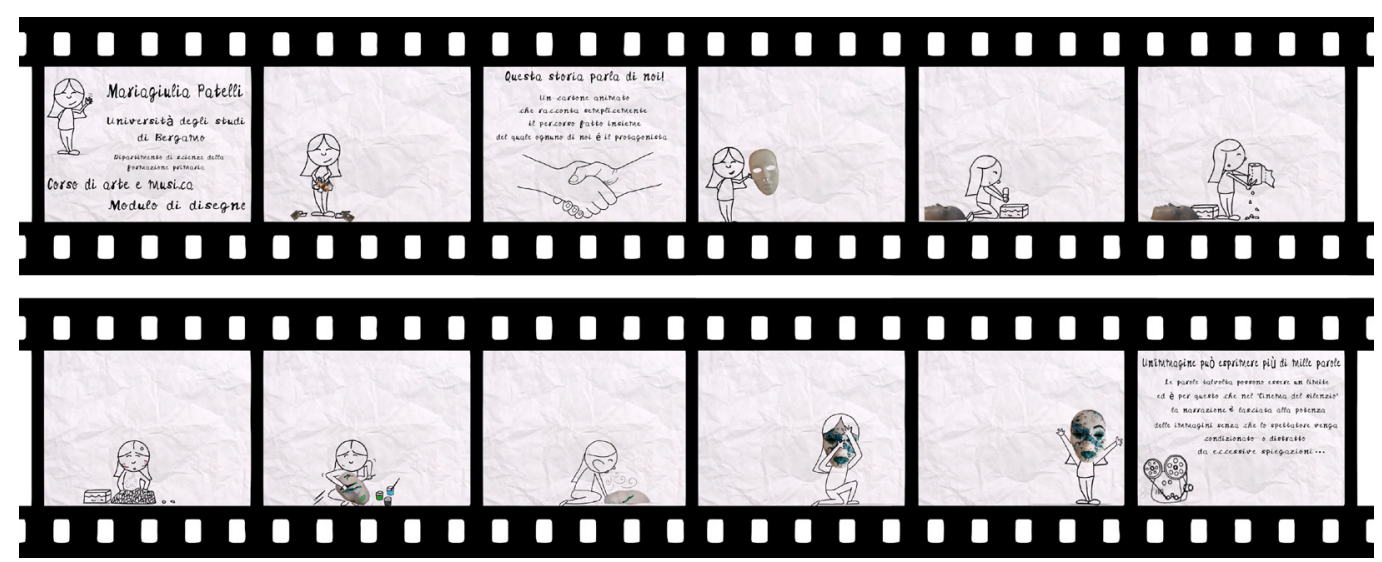

La struttura didattica della lezione: II coinvolgimento attivo, intenso e continuo degli studenti all'attività didattica è una delle priorità ricercate dal corso. Ė essenziale limitare i tempi inattivi o di minore attenzione al fine di evitare distrazioni o estraniazioni, anche attraverso il coinvolgimento dei ragazzi in uno sforzo fisico e stancante.

A tal fine la lezione è scandita in quattro sequenze temporali aventi, ognuna, delle caratteristiche specifiche, la fase A di comunicazione frontale, la fase B di preparazione all'esercitazione, la fase $C$ di applicazione pratica e la fase $D$ di dialogo critico sulle attività svolte.

- La fase A, organizzata secondo le modalità tradizionali di iterazione tra docente e discente, si attua con l'illustrazione dei fondamenti teorici della disciplina e la dissertazione sugli argomenti della lezione. La comunicazione verbale avviene contemporaneamente allo spostamento continuo del professore all'interno dell'aula, in modo tale da 'disorientare' gli studenti e richiedere sempre la loro attenzione. La prassi vuole che il docente si muova accanto o dietro ai ragazzi (non innanzi a loro perché i suoi gesti possono essere motivo di distrazione) in modo che essi ascoltino solo la sua voce senza vederne la figura e siano indotti a rivolgere lo sguardo verso lo schermo. Gli argomenti, raggruppati in sezioni tematiche, devono essere trasmessi allinterno della curva di attenzione per poi stimolare una risposta pronta e intelligente con un dialogo con gli studenti sulle questioni appena trattate; tutto questo è finalizzato a un rapido apprendimento e le riflessioni, a cui i ragazzi sono stimolati e obbligati, sono uno strumento basilare per memorizzare e consolidare le informazioni appena ricevute.

- La fase B è impostata su un'attività motoria dove i ragazzi affaticando il fisico e coordinando i propri movimenti, meditano sui concetti appena ricevuti e 'aprono la mente alla creatività'. Gli studenti vengono invitati ad alzarsi, a muoversi nello spazio, a guardare raffigurazioni e opere di grandi artisti del disegno e della pittura per commentarle tra loro in piccoli gruppi. Si chiede loro di camminare seguendo un ritmo musicale sempre più elevato 
sino a correre per poi fermarsi all'improvviso e sedersi a terra. Si domanda loro di saltare, gridare, farsi condurre all'interno dell'aula bendati, affidandosi completamente a un compagno. Avvolti dal buio, gli si chiede, inoltre, di toccare degli oggetti e/o di sentirne l'odore per immaginarli e riconoscerli senza l'ausilio della vista. Una preparazione fondata sulle modalità di apprendimento del cooperative learning e integrata a tecniche di psicomotricità e comunicazione teatrale, finalizzata a stimolare il rapporto casuale e l'iterazione tra individui. Gli esercizi fisici (lavorare con il corpo) e l'accidentalità nell'occupare lo spazio permette al docente di scardinare la creazione volontaria dei gruppi che, invece, si costruiscono per situazioni fortuite non volute e/o previste dagli allievi; tutto questo rafforza gli scambi interpersonali, stimola il senso di appartenenza alla classe, incoraggia la fiducia verso gli altri. Esercizi particolari dove l'azione ha un effetto sul comportamento per abbattere i preconcetti; l'agire 'in modo strano' ed inusuale ha, ad esempio, lo scopo di far perdere il senso del possesso personale per favorire invece la condivisione, nonché di facilitare l'aggregazione e l'integrazione all'interno dei gruppi 'del diverso' e/o di chi 'non ci è simpatico' forse perché 'non gli abbiamo mai rivolto la parola' e giudicato semplicemente sulla base di canoni estetici e di appartenenza sociale.

- La fase C, è la parte esperienziale del workshop dove gli studenti sono chiamati a mettersi in gioco e realizzare le proprie opere. Benché alcuni laboratori possano essere sviluppati autonomamente la maggior parte di essi è immaginata in gruppo. L'opera nasce dallo scambio di idee, dal confronto e dallo scontro continuo con i propri compagni, dallo stimolo che può

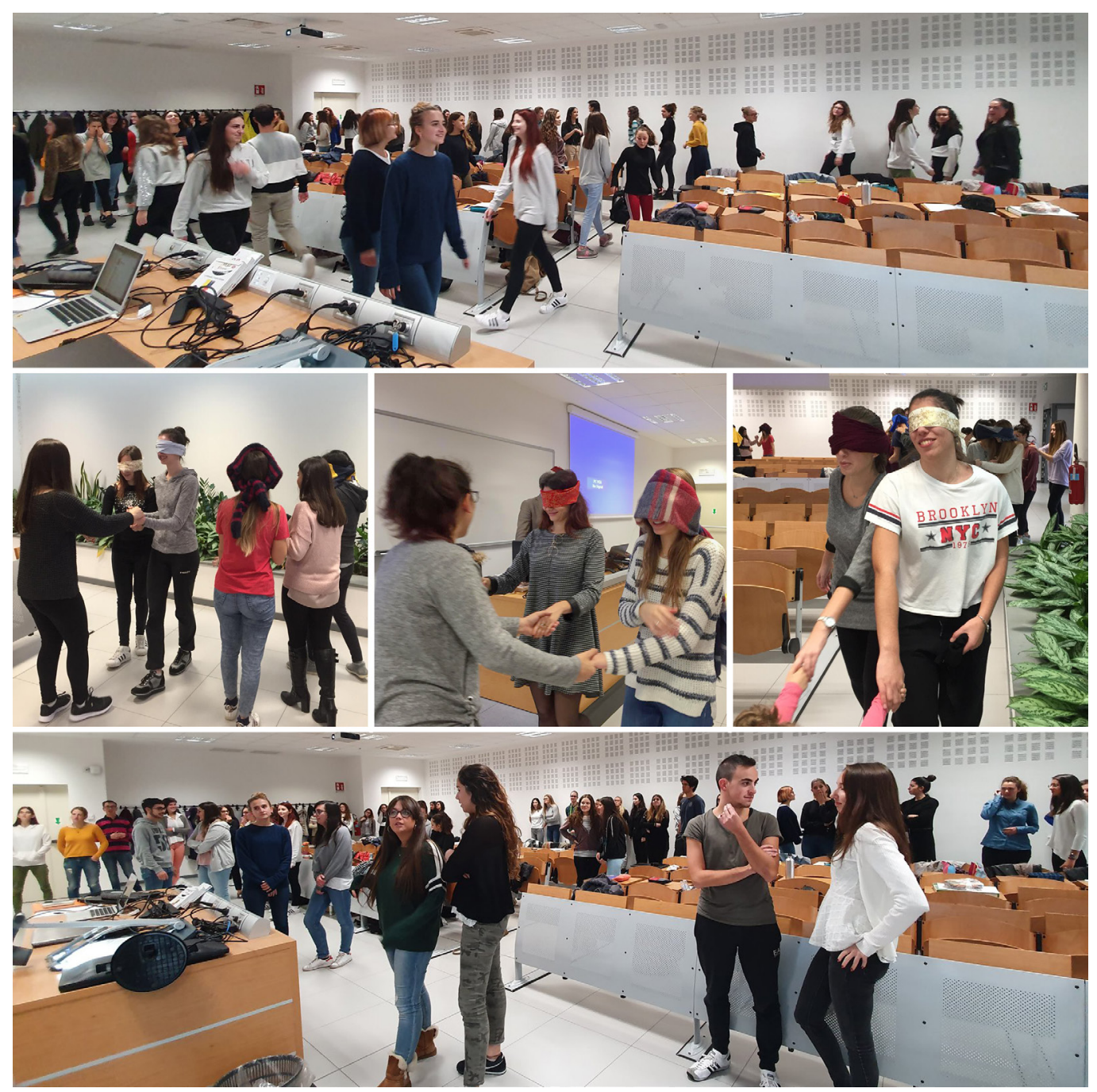


nascere dall'osservare il lavoro dei gruppi vicini. Le modalità di esecuzione sono molto libere e senza confinamenti e indicazioni preliminari; il limite è non porre alcun limite alla propria fantasia (ovviamente all'interno delle regole del buon senso e della buona educazione). I ragazzi si organizzano per lavorare dove è per loro più idoneo, utilizzano corridoi e pavimenti per stendere i cartoncini e impiegare i colori e i materiali di riciclo nei modi più fantasiosi; le vetrate sono l'occasione per ridisegnare e interpretare quadri e/o immagini a cui daranno un nuovo senso e una nuova interpretazione.

- La fase D, è la fase conclusiva dedicata all'esposizione, commento e giudizio sull'esperienza. I lavori sono appesi alle pareti o posti a terra in modo tale da essere ammirati dalla classe; una galleria museale per permettere ai ragazzi una riflessione basata sulla comparazione del proprio lavoro con il lavoro degli altri. Muovendosi accanto alle opere è possibile lasciare dei commenti scritti, dei suggerimenti e, eventualmente, delle critiche purché motivate. II dibattito avrà inizio da questi 'giudizi' impiegati dal docente per favorire la discussione: si chiede ai 'maestri' di raccontare, ad alta voce ai propri colleghi, le proprie considerazioni personali. Una fase 'accesa' di scambio di opinioni per riflettere sul percorso, impossessarsene, e ripensarlo ricondizionato in base alla propria volontà di miglioramento. Una breve sintesi e i saluti del docente concluderanno repentinamente il dibattimento al fine di non far decadere l'interesse verso il dibattito; una chiusura 'inaspettata' lascerà 'l'amaro in bocca agli studenti' che allontanandosi dall'aula continueranno ad alimentare la conversazione tra di loro.
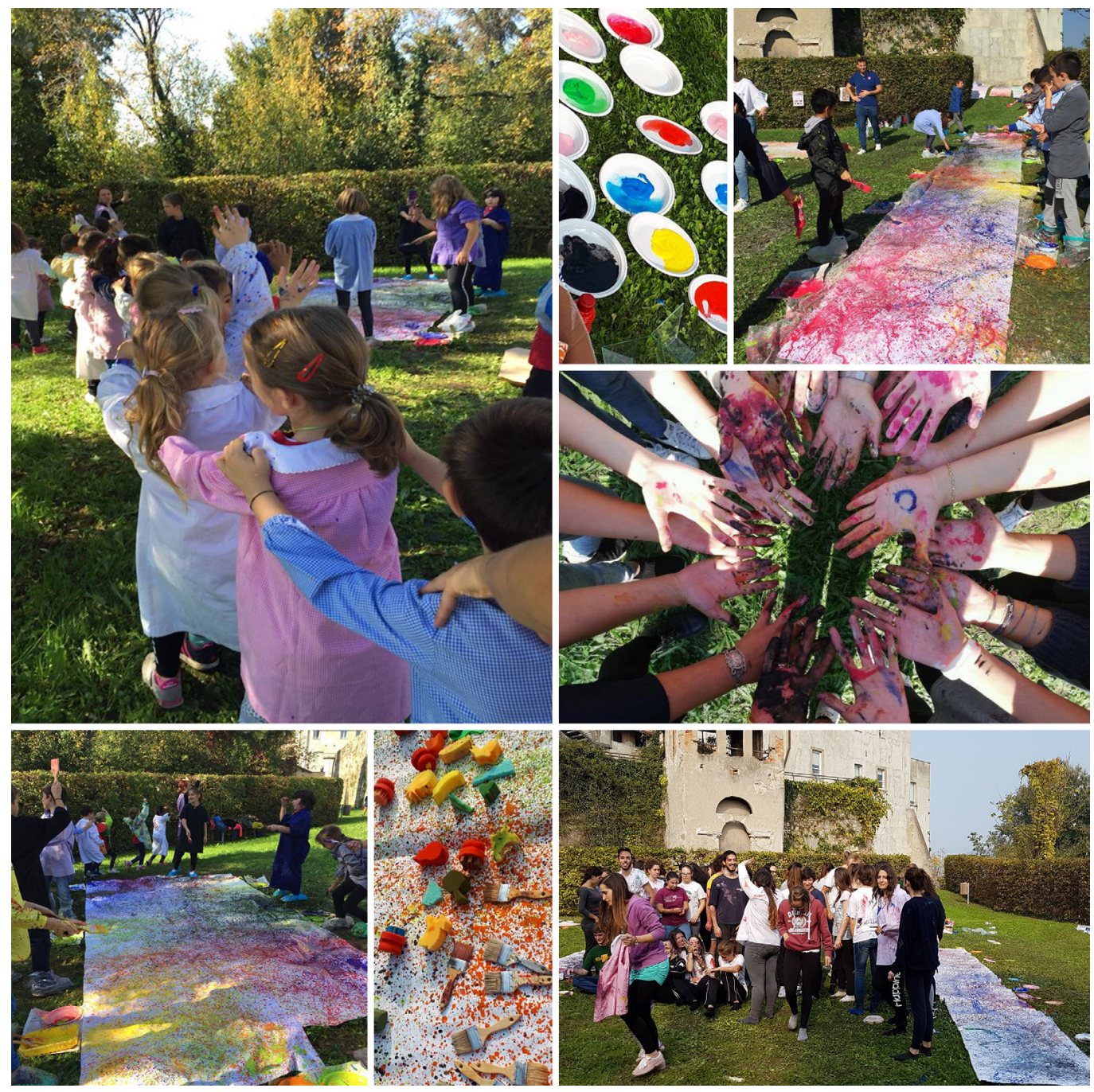
Fig. 6. Laboratorio didattico "lo e la mia maschera": gli studenti, dopo aver schere, le proprie maschere, le hanno animate rappresentazione teatrale aperta al pubblico.
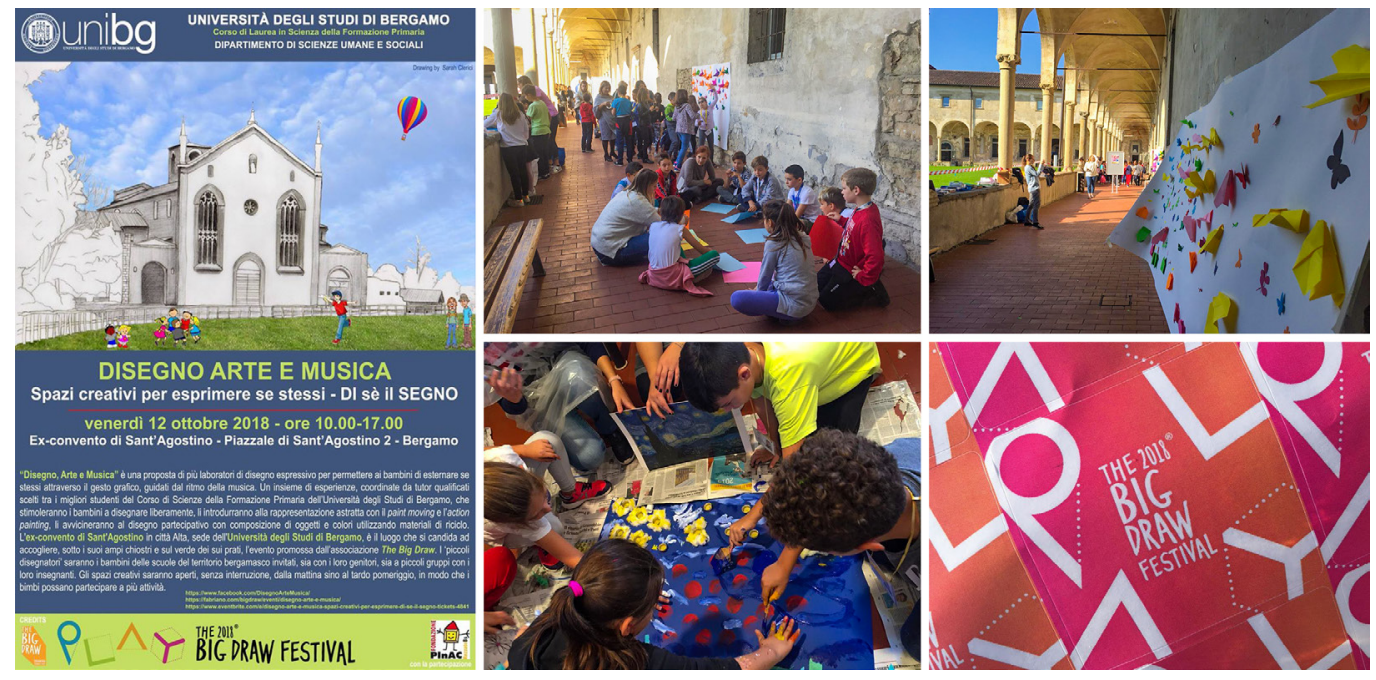

Il sistema di valutazione (il portfolio, il prodotto multimediale e il progetto didattico): la frequenza dei laboratori e la partecipazione al lavoro di gruppo garantiscono il superamento dell'esame. L'allievo seguendo il percorso formativo del docente acquisisce, nel mentre, le competenze necessarie per raggiungere gli obbiettivi richiesti. La votazione è basata sull'impegno e sulla progressione, valutata volta per volta in aula, più che sulla qualità dei lavori. Un Disegno è infatti unico e personale, incomparabile e immisurabile; non è possibile giudicarlo, soltanto attribuendogli un 'numero' perché questo impone una classifica di merito, esattamente il contrario di quanto il corso vuole insegnare. Non esiste il Disegno più bello perché ogni Disegno è splendido come tutti gli altri, purché sia fatto con impegno e con il cuore. È richiesto, quindi, agli studenti di narrare, in modo personale, la sua esperienza attraverso un portfolio e un prodotto multimediale (un cartoon, un video, un breve cortometraggio), nonché di redigere un progetto didattico.

Il portfolio è una relazione in cui il candidato si presenta, illustrando i suoi interessi, le sue aspettative, parlando delle motivazioni che lo hanno indotto a voler 'diventare un maestro'. I ragazzi si descrivono sia attraverso una loro fotografia (come le immagini di facebook che mostrano la persona e ne esaltano il carattere), sia per mezzo di un'immagine che parla di sé: una fotografia, un disegno, un'opera d'arte, atte a comunicare il mondo in cui si identificano e i riconoscono. Il portfolio contiene la raccolta dei lavori e per ogni opera è richiesto
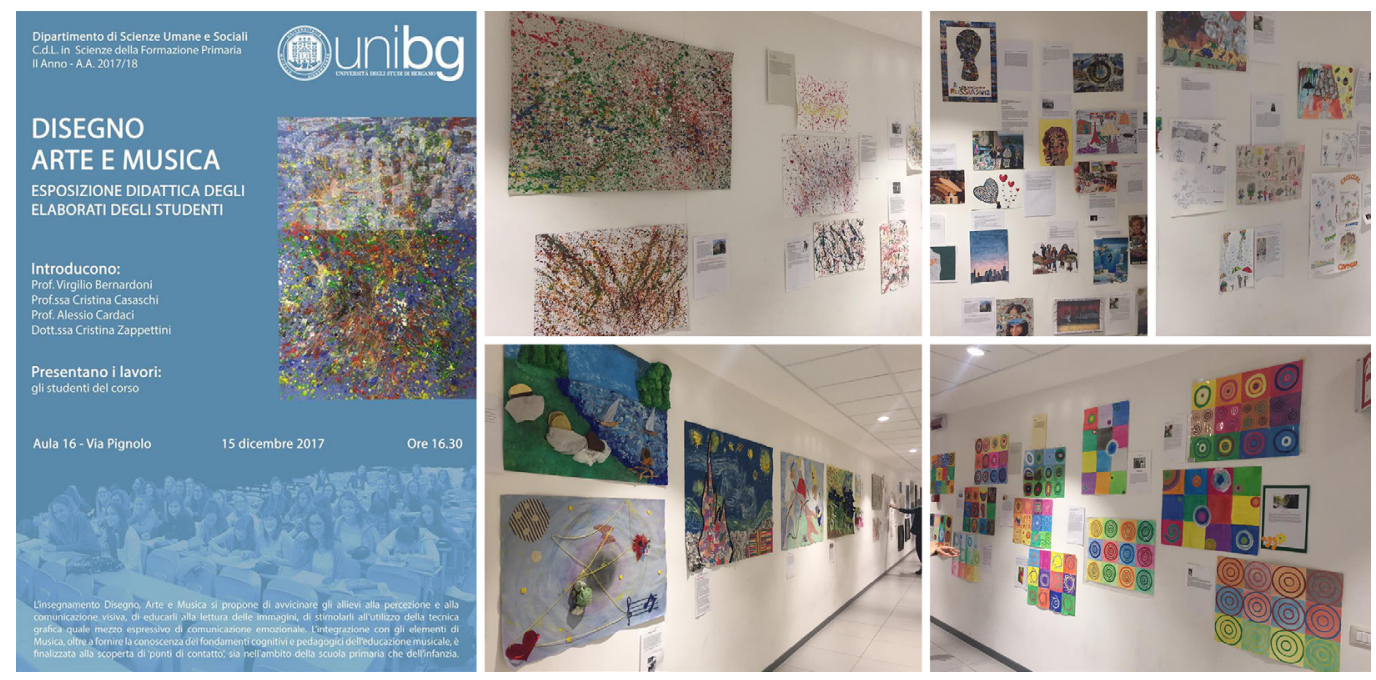

Fig. 7. La pagina Facebook: i prodotti multimediali degli studenti sono divulgate online, anche al fine
di permettere lo scambio di esperienze e stimolare nuove idee. 
Fig. 8. I prodotti multimediali. Esempio di un cartoon che descrive il percorso formativo dello studente.

Fig. 9.1 prodotti multimediali. Esempio d cortometraggi realizzati dagli studenti per 'narrare' il percorso formativo dell'insernativo Disegno per l'infanzia.
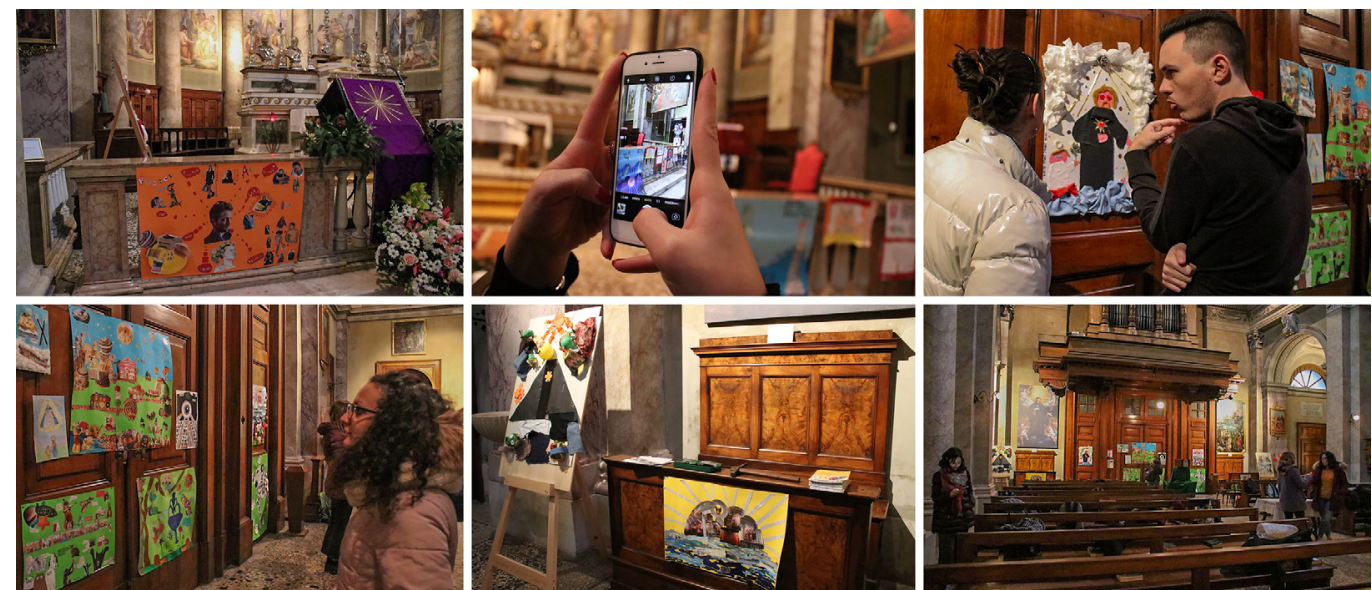

un titolo e la giustificazione della scelta, spiegando cosa si è voluto comunicare, perché lo si è realizzato, cosa si e pensato mentre lo si componeva, la scelta della tecnica e degli strumenti. Importantissimo è, dopo aver realizzato la creazione, ricercare le nozioni teoriche e i contenuti concettuali all'interno dei libri di testo consigliati, nonché commentarli criticamente. II prodotto multimediale è un filmato, limitato a un massimo di qualche minuto, in cui lo studente deve narrare il suo percorso; i risultati sono i tra i più particolari e imprevedibili, dalla creazione di semplici sequenze di immagini a veri film in costume basati su una scenografia e dialoghi. II Disegno di manifesta all'interno delle altre arti, come la danza o il teatro. I ragazzi sono stimolati nel realizzare un prodotto particolare perché sono consci del fatto che tutto ciò che sarà da loro creato sarà pubblicato online sia su un canale youtube (https://

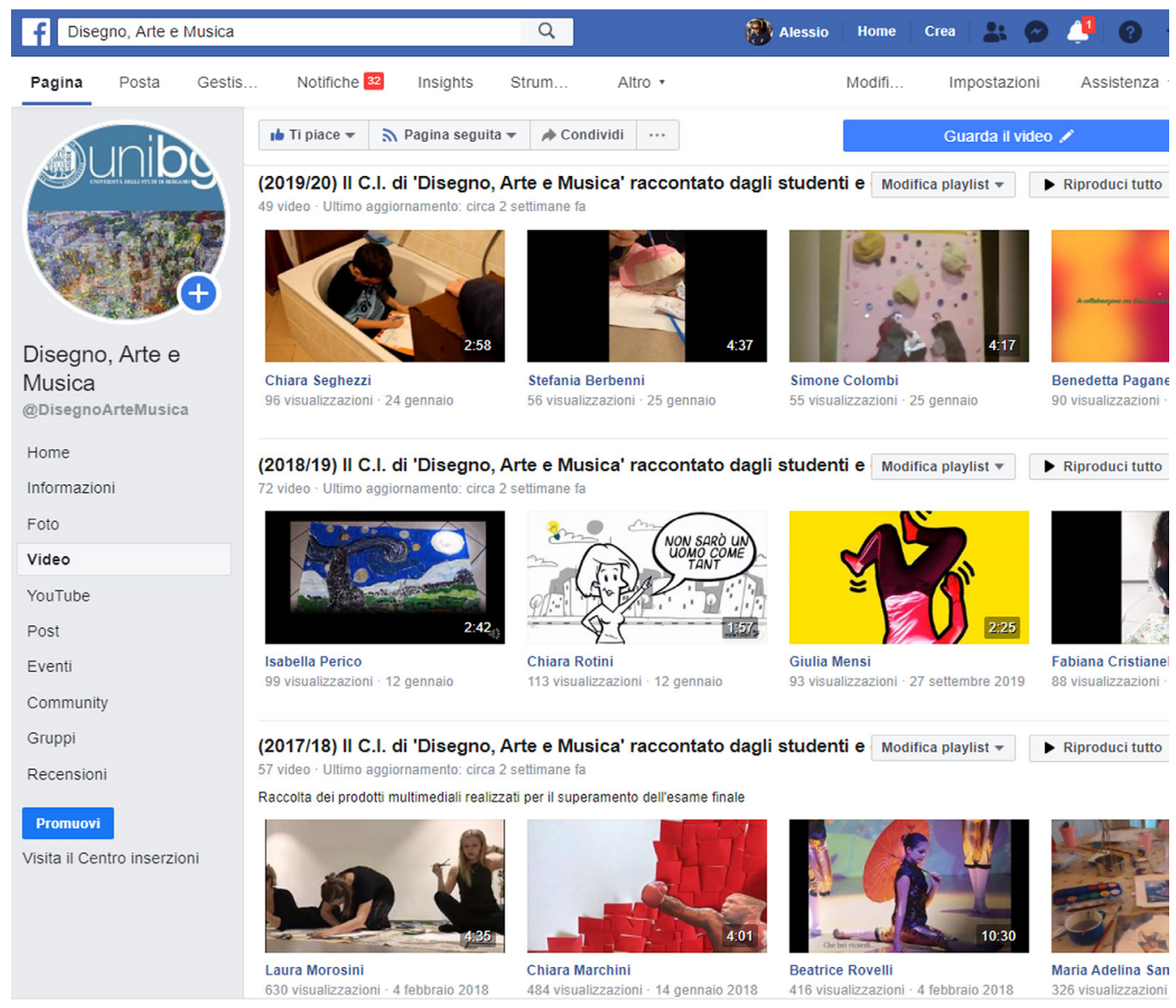


Fig. 10. The Big Draw: il festival offre agli studenti l'opportunità di attuare loro progetti didattici: le scuole e le famiglie sono inviatati a partecipare ai laboratori pensati, gestiti ed organizzati dagli
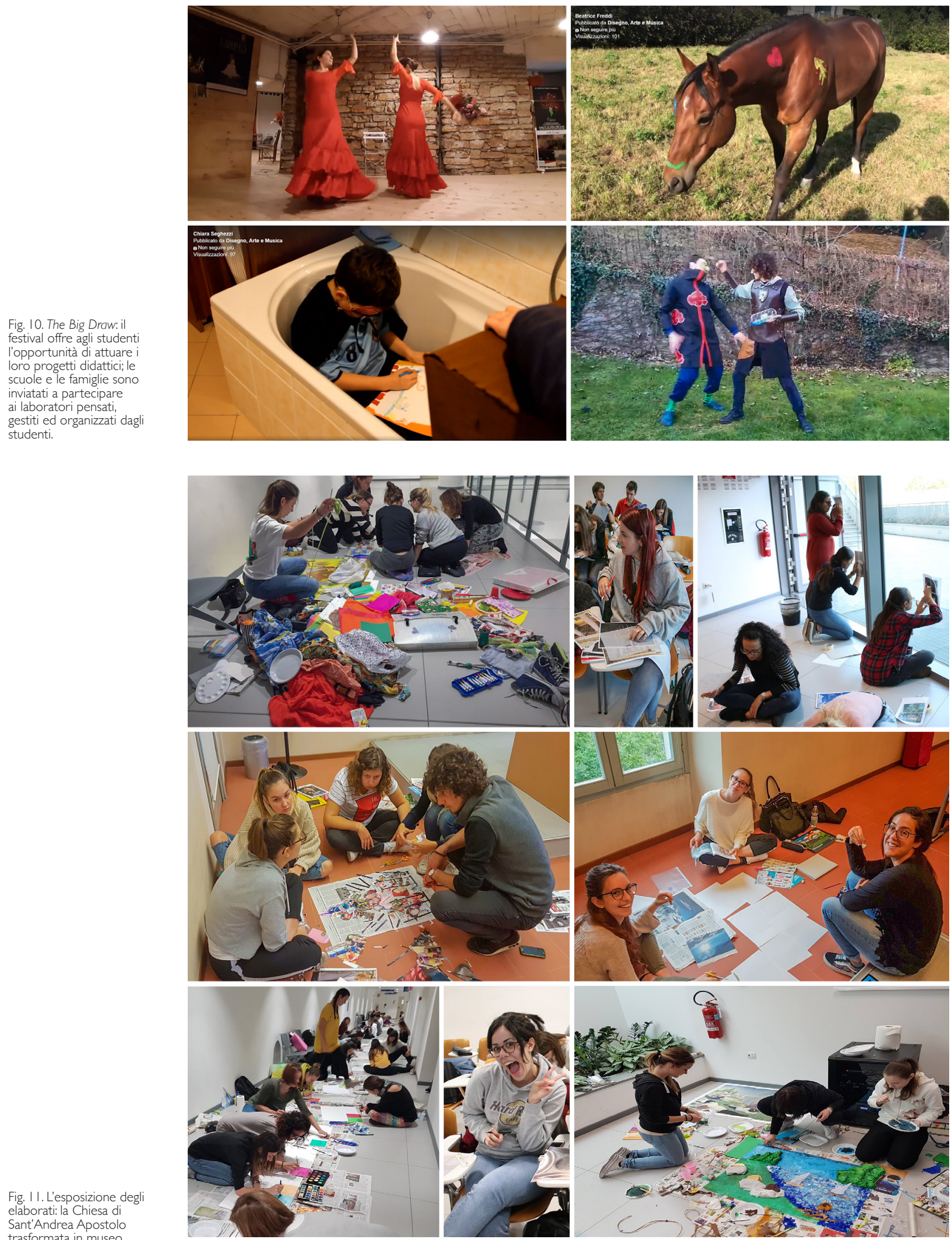
www.youtube.com/channel/UCAWhap72WUDDk2wHroraHiw) dedicato, sia attraverso la pagina facebook (https://www.facebook.com/DisegnoArteMusica/) del corso. Una sfida che si istaura tra gli studenti al fine di far acquisire più like ai loro prodotti e che permette la divulgazione e i contenuti del corso a un pubblico vasto e variegato.

Il progetto didattico nasce dall'osservazione degli studenti all'interno delle scuole grazie al percorso di tirocinio. I ragazzi, assistendo come spettatori a un laboratorio artistico, sono chiamati a compilare una scheda nella quale indicare la finalità del progetto, riportare l'attività con la narrazione esplicativa delle varie fasi di lavoro e le eventuali integrazioni con altre discipline, indicare le metodologie didattiche e materiali impiegati, descrivere gli spazi e gli allestimenti; essi sono anche chiamati a verificare se i contenuti formativi e progettuali seguono le indicazioni nazionali del MIUR e a esprimere un giudizio finale di merito. Su queste basi i ragazzi sono quindi chiamati a inventare una propria attività, progettandola come se fosse un proprio laboratorio. II progetto è redatto partendo da un titolo, per poi essere sviluppato secondo i dati indentificativi, i contenuti formativi e la descrizione delle fasi, gli obbiettivi e i traguardi da raggiungere, luoghi di svolgimento e tecniche da adottare. Una parte di questi progetti è attuata grazie all'opportunità offerta dal festival The Big Draw, uno spazio che si ripete ogni anno e in cui l'università si apre alla città e invita le scuole e le famiglie a partecipare a esperienze totalmente pensate, gestite e organizzate dagli studenti; il loro primo passo per diventare educatori e 'mettere in pratica' quanto hanno appreso.
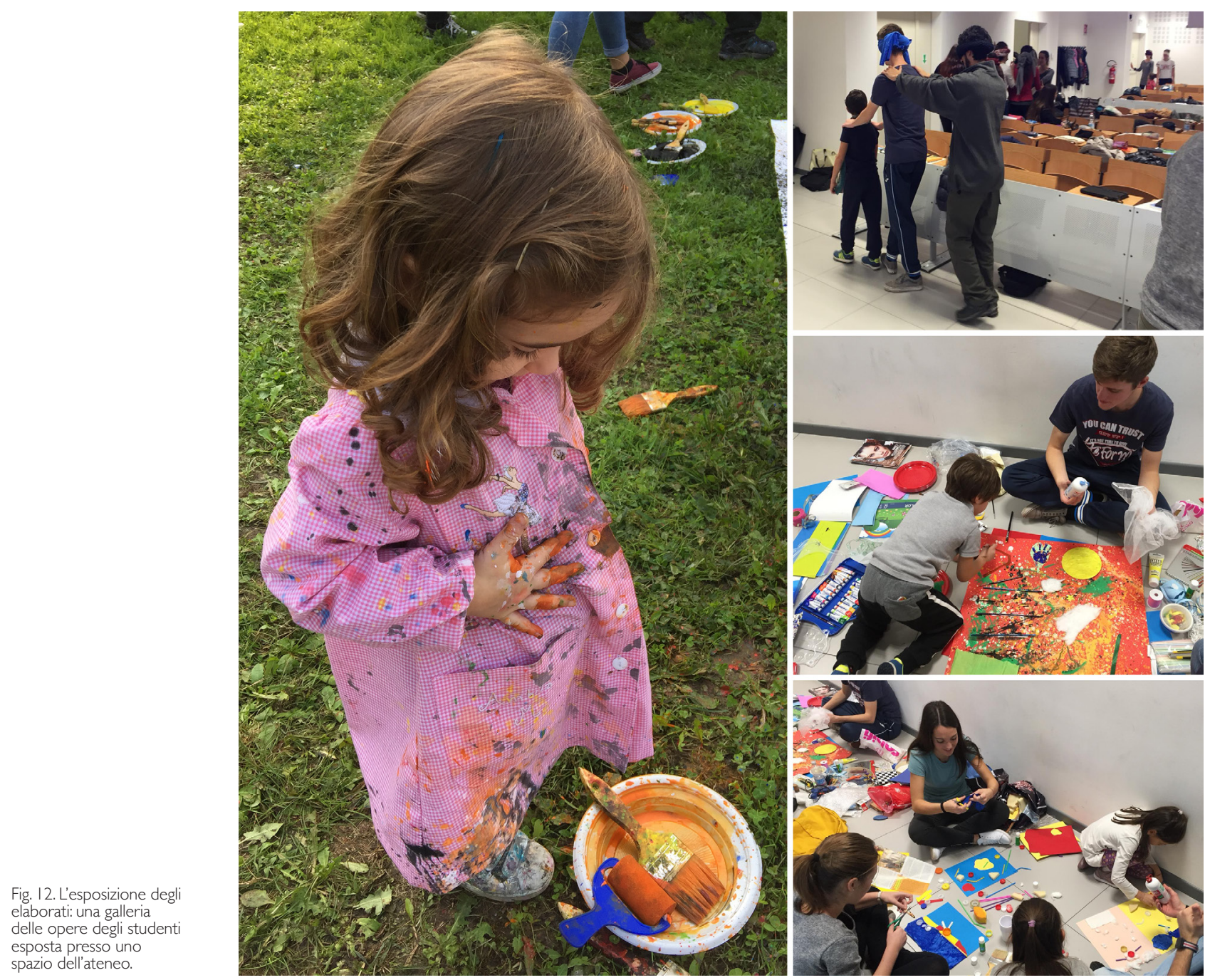


\section{Conclusioni}

L'insegnamento del Disegno nell'ambito dei corsi di Scienza della Formazione Primaria è molto variegato e basato sulla personale interpretazione del percorso formativo da parte del docente. Benché le indicazioni ministeriali individuino i contenuti dell'insegnamento, queste sono molto generiche e poco descrittive dei metodi e delle tecniche didattiche che è opportuno adottare. II nostro settore disciplinare ha tentato, in questi ultimi anni, di avere coscienza delle varie esperienze sul territorio nazionale, incentivando l'organizzazione di numerosi convegni e seminari sul tema; questi hanno prodotto un ricco scambio tra i docenti e avviato a un dibattito sul futuro di questa particolare declinazione della disciplina. Purtroppo, sono ancor 'oggi mancanti delle direttive 'ufficiali' e un quadro di sintesi completo, nonché una 'manualistica' e una bibliografia didattica di riferimento, a cui si auspica si possa addivenire (forse a seguito di un grande congresso nazionale) al fine di valorizzare e non disperdere il bagaglio di competenze maturato dai 'pionieri' del Disegno per l'infanzia [I].

\section{Note}

[I] Un sincero ringraziamento al prof. Giuseppe Bertagna, coordinatore del corso di Laurea in Scienza della formazione Primaria presso l'ateneo di Bergamo, per la fiducia riposta nella mia persona e per la disponibilità nel condividere le mie idee e nell'incoraggiare le mie scelte didattiche. Un particolare ringraziamento al prof. Virgilio Bernardoni, docente del modulo di Musica, e alla dott.ssa Cristina Zappettini, esercitatrice del modulo di Disegno e Arte, per il fondamentale supporto - fondato su un rapporto di stima e la collaborazione - nelle attività congiunte dell'insegnamento. Un grazie ai colleghi del dipartimento di Scienze Umane e Sociali della mia università per il continuo scambio di idee e opinioni; i loro consigli e i loro suggerimenti hanno aiutato a costruire la didattica del corso.

\section{Riferimenti bibliografici}

Appiano Ave (2008). Comunicazione visiva: apparenza, realtà, rappresentazione. Milano: Utet.

Carluccio Carolina (2004). Educazione all'immagine. Napoli: Cues.

Carluccio Carolina (2008). Disegno arte immagine. Napoli: Cues.

González Álvarez Sandra, López Bahut María Emma (2017). La Ciudad del mañana. A Coruña: PØSTarquitectos COAG.

Hachen Massimo (2007). Scienza della visione: spazio e gestalt, design e comunicazione. Milano: Apogeo.

Luigini Alessandro, Panciroli Chiara (2018). Ambienti digitali per l'educazione all'arte e al patrimonio. Milano: Editore FrancoAngeli. Pallasmaa Juhani (2005). The eyes of the skin: architecture and the senses. Chichester:Wiley-Academy.

Panciroli Chiara (20I2). Arti visive nella didattica.Verona: QuiEdit Edizioni.

Tonucci Francesco (2005). La città dei bambini: un modo nuovo di pensare la città. Roma-Bari: Laterza.

Van Eyck Aldo (2008). The Child. the City. and the Artist. Amsterdam: Sun Publishers.

\footnotetext{
Autore

Alessio Cardaci, Università di Bergamo, alessio.cardaci@unibg.it
}

Per citare questo capitolo: Cardaci Alessio (2020). Il disegno per l'infanzia: approcci interdisciplinari per una nuova forma/The drawing for children: interdisciplinary approaches to a new form of education. In Arena A., Arena M., Brandolino R.G., Colistra D., Ginex G., Mediati D., Nucifora S. Raffa P. (a cura di). Connettere. Un disegno per annodare e tessere. Atti del $42^{\circ}$ Convegno Internazionale dei Docenti delle Discipline della Rappresentazione/Connecting. Drawing for weaving relationships. Proceedings of the 42 th International Conference of Representation Disciplines Teachers. Milano: FrancoAngeli, pp. 21 6-237. 


\title{
The Drawing for Children: Interdisciplinary Approaches to a New Form of Education
}

\author{
Alessio Cardaci
}

Abstract

The teaching of Drawing within the degree courses in Primary Education Sciences calls for new reflections in our sector aimed at remodelling of teaching no longer to the training of engineers and architects but of educators. A professional figure who uses the graphic tool, not for the understanding and enhancement of architecture and landscape, but as a fundamental tool for communicating the child's inner space. An enlarged conception of the discipline, without a direct link with the representation of the architectural and natural heritage, based on a close relationship with visual art together with the doctrines of art history and social sciences. On these bases, a particular - perhaps experimental - teaching was installed at the University of Bergamo, which entrusted the role of Drawing, both as a correlation between artistic and musical education, and as a permeating membrane of relationship with the discipline psychological and pedagogical.

Keyword

cooperative learning, art and music, primary school, pedagogy, psychology, Bergamo.

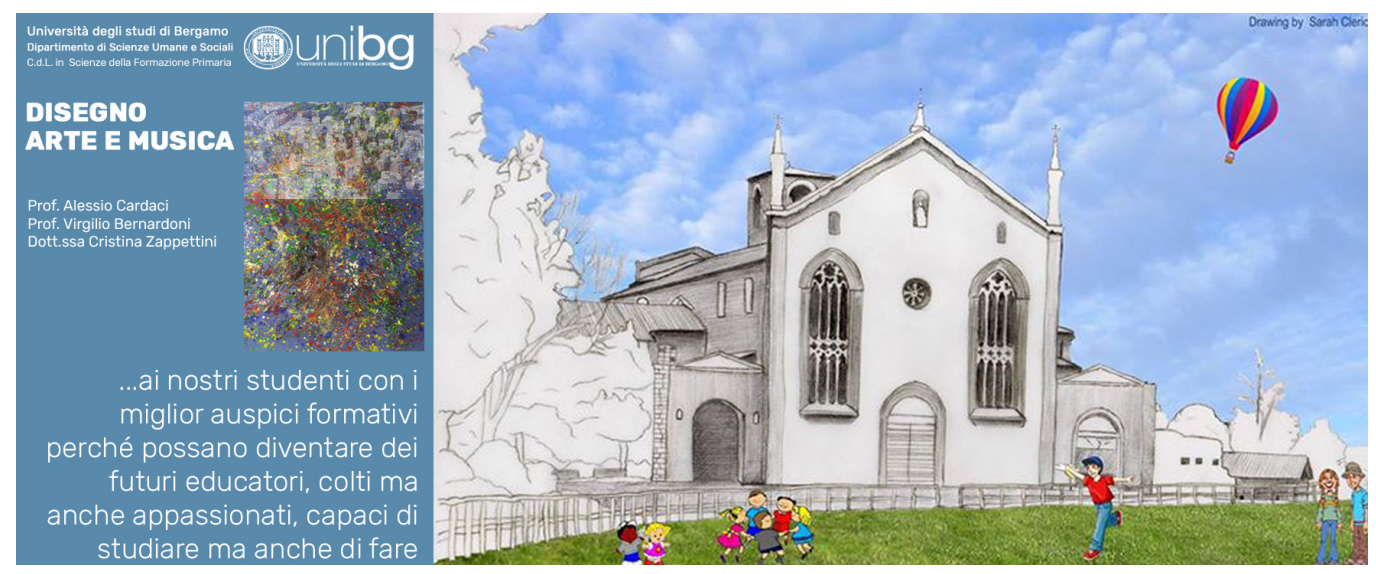




\section{The role of drawing in primary education sciences}

The training course in Primary Education Sciences prepares to become teachers of kindergarten and elementary school. A five-year single-cycle degree program with a programmed number, aimed at promoting job placement through a qualifying qualification for the profession. An offer addressed both to young graduate students and to 'old teachers' and kindergarten educators who wish to acquire a degree of professional improvement and their job position. The course in Primary Education Sciences, more than a study cycle "is a real learning community" based on strong interdisciplinarity and a close interrelation with the world of school. The role of the primary teacher is to start the child learning and stimulate curiosity towards him in knowledge; a process aimed at promoting cultural literacy, based on the pleasure of discovery and one's individuality. The primary school teacher must contribute, together with the family, during the nursery school "to the emotional, psychomotor, cognitive, moral, religious and social development of girls and boys" and, during the first cycle of education "to favour the socialization and the acquisition of the first basic knowledge and skills" (DL 59, 2004).

Cognitive and psychological development, as well as logical-relational skills, must take place thanks to a playful-educational activity that stimulates creativity, autonomous thinking and social relationships. A path in which the transmission of knowledge of the individual discipline takes on a secondary function within a broad and interdisciplinary dialogue.

The study plans offered by the various university sites, not very dissimilar to each other due to the national system, are clear proof of this; they are based on basic pedagogical teachings completed by a vast number of characterizing subjects. The teaching of Drawing (SSD Icar / 17) is included within the "Disciplines of the Arts", together with the doctrines of the history of modern and contemporary art, as well as the study and narration by an image of cinema, photography and television. An enlarged conception of Drawing, without a direct link with the representation of the built reality and the territorial and landscape context, based on a close relationship with the visual arts and aimed at image education through the knowledge of the tools and techniques of representation in the various artistic areas.

This calls for a serious commitment of our sector for a reflection and modulation of teaching, no longer aimed at the training of engineers and architects but of educators; professional figures who will have to use the Drawing not for the understanding and enhancement of architecture, the anthropic and natural environment, but to use it as a fundamental tool for communicating the child's interior space. On this basis, a special -perhaps experimentalteaching was designed at the University of Bergamo, which entrusted the role of Drawing, both as a correlation between artistic and musical education, and as a permeating membrane of relationship with the disciplines psychological and pedagogical.

Fig. I.The teaching structure of the lesson: the students are physically engaged in the activities by running, walking blindfolded, stopping suddenly to comment on the slides in groups.
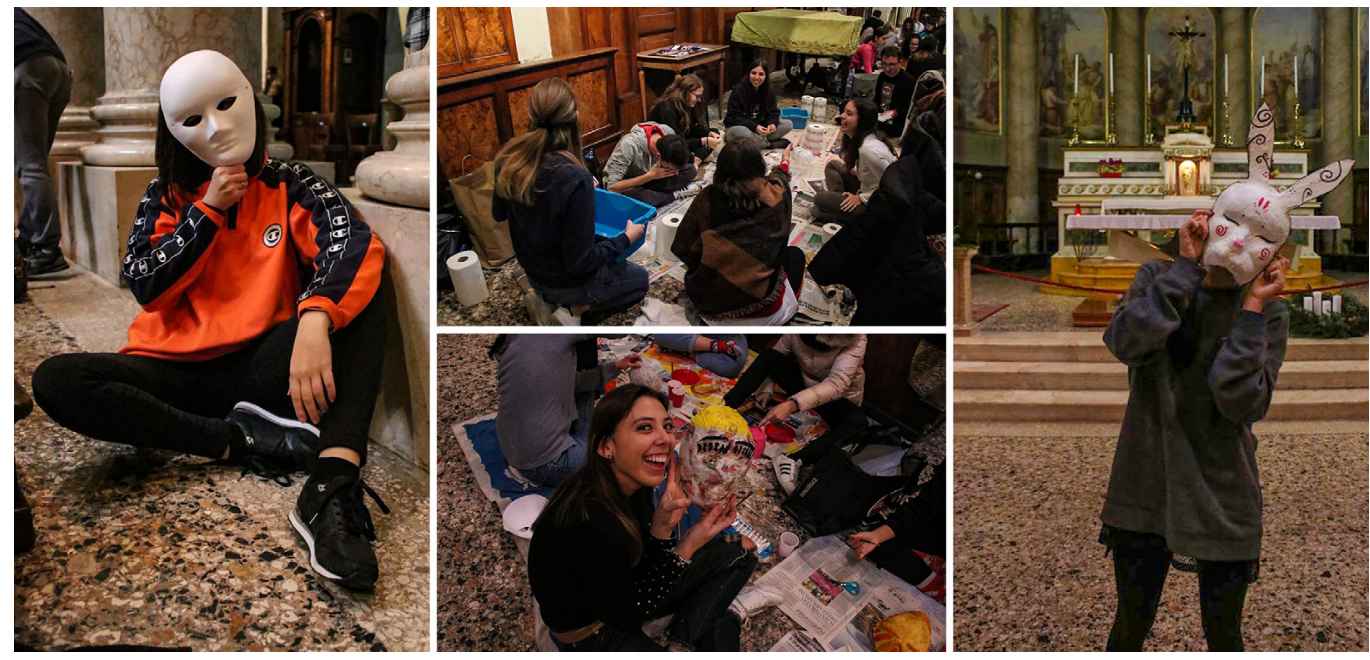


\section{The C.I of drawing, art and music at University of Bergamo}

Teaching premises:The C.I of Drawing, Art and Music active at the University of Bergamo is teaching born from the integration of skills between the sectors of pedagogy, psychology and the science of representation. The course aims to bring students closer to perception and visual communication, to educate them to read images, to stimulate them to use the graphic technique as an expressive means of emotional communication. A vision of the Design that intends to re-attribute the meaning "OF SIGN to oneself" to the noun, relating the activities to the individual who uses shapes and colours to express their inner world. Here, then, is the design of a series of activities that have as a common element to bring them closer and, hopefully, to make students passionate about drawing and graphic communication. It is, in fact, necessary for new teachers to fall in love with the discipline to communicate it to children and, subsequently, bring them closer to the graphic act as a natural and spontaneous gesture dictated by the involvement and the need to communicate their innermost and deeper self.

The teaching aims to convey the spirit of the doctrine but, above all, to make future 'masters' understand that it is possible to manifest one's infinity both through the manual skills of free drawing, and through the knowledge and use of tools suitable for figuration (traditional and digital). The science of representation is not the simple instruction to knowledge related to the technique and methodology of representation, but the materialization of a thought that manifests itself through the graphic sign.

This is achieved thanks to the workshops and laboratory activities that aim to bring students back to being infants; go back to childhood to get closer to expressive and compositional design. Only if they are passionate about what they are doing on this path will they, tomorrow, guide the children - with the same love and the same transport - on the same road that has seen them protagonists in their academic life. The lessons, during the course, must "regress" the class to childhood, to face the assigned exercises; students are therefore actors who have to identify and act - with unconsciousness and unawareness- the role of kindergartens and elementary school pupils.

The workshops focus on two main themes: emotional drawing and drawing for the construction of the image. The exercises related to emotional drawing (for example textures, lab-pollock, 3D puzzle, me and my mask, ...) are mainly aimed at the pre-school path aimed at children from 2 to 6 years of age, as an integral part of a precise interdisciplinary educational project. The purpose of the exercises related to the Drawing for the construction of

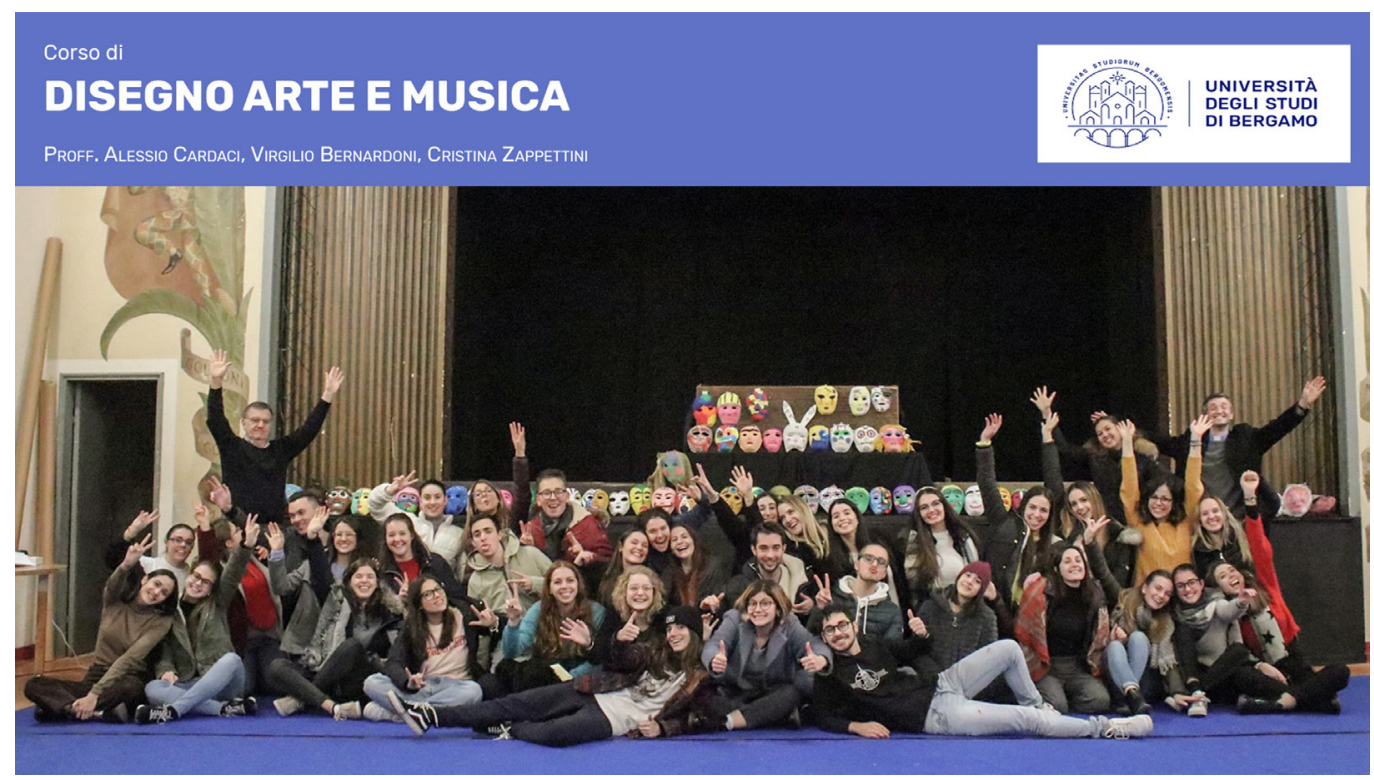


Fig. 3. The teaching the Pollack lab lesson: (hildren's participation cons cises with siblings, exercises with siblings, sisters the image (such as the photo-collage, the composition of comics, the redesign of the images, The shared drawing, ...), however, is the creation of a complex image, composition of simpler images; they are therefore designed for primary education in which children, from the age group of 7 to 12 years, have already acquired the necessary graphic technique and the ability to use the tools of representation.

The teaching structure of the lesson: The active, intense and continuous involvement of students in teaching is one of the priorities sought by the course. It is essential to limit downtime or less attention to avoiding distractions or estrangements, also through involving the children in a physical and tiring effort.

To this end, the lesson is divided into four-time sequences, each with specific characteristics, phase A of frontal communication, phase B of preparation for the exercise, phase $C$ of practical application and phase D of critical dialogue on the activities carried out.
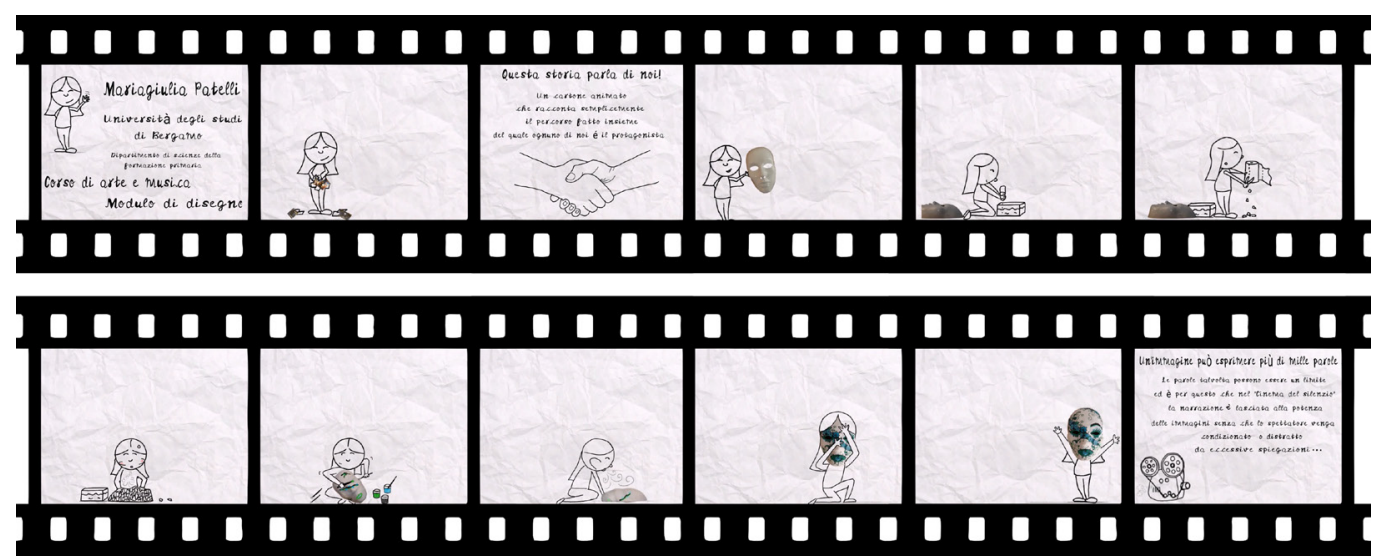

- Phase A, organized according to the traditional iteration methods between teacher and learner, takes place with the illustration of the theoretical foundations of the discipline and the dissertation on the topics of the lesson. Verbal communication takes place simultaneously with the continuous movement of the professor within the classroom, to 'disorient' the students and always ask for their attention. Practice requires that the teacher moves beside or behind the boys (not in front of them because his gestures can be a distraction) so that they listen only to his voice without seeing the figure and are induced to turn his gaze towards the screen. The topics, grouped into thematic sections, must be transmitted within the attention curve to then stimulate a prompt and intelligent response with a dialogue with students on the issues just discussed; all this is aimed at rapid learning and the reflections, to which the children are stimulated and obliged, is a basic tool for memorizing and consolidating the information just received.

- Phase B is set on a motor activity where the boys, by fatiguing the body and coordinating their movements, meditate on the concepts just received and "open the mind to creativity". Students are invited to get up, to move in space, to look at depictions and works of great drawing and painting artists to comment on them in small groups. They are asked to walk in an increasingly high musical rhythm until they run and then stop suddenly and sit on the ground. They are asked to jump, shout, get blindfolded into the classroom, completely relying on a companion. Enveloped in the dark, he is also asked to touch objects and / or smell them to imagine and recognize them without the aid of sight. A preparation based on the methods of learning cooperative learning and integrated with psychomotor techniques and theatrical communication, aimed at stimulating the casual relationship and the iteration between individuals. Physical exercises (working with the body) and accidentality in occupying space allow the teacher to disrupt the voluntary creation of groups which, on the other hand, are built for unintended and / or foreseen accidental situations by the 
students; all this strengthens interpersonal exchanges, stimulates a sense of belonging to the class, encourages trust in others. Particular exercises where action affects behaviour to break down preconceptions; acting 'in a strange' and unusual way has the purpose, for example, of losing the sense of personal possession to favour sharing, as well as of facilitating the aggregation and integration within 'different' groups and/or those who 'do not like us' perhaps because 'we never spoke to him' and judged simply based on aesthetic standards and social belonging.

- Phase $C$ is the experiential part of the workshop where students are called to get involved and carry out their works. Although some laboratories can be developed independently, most of them are imagined as a group. The work arises from the exchange of ideas, from the confrontation and the continuous clash with one's companions, from the stimulus that can arise from observing the work of neighbouring groups. The execution methods are very free and without confinements and preliminary indications; the limit is not to put any limit on one's imagination (obviously within the rules of common sense and good manners). The boys organize themselves to work where it is most suitable for them, use corridors and floors to lay out the cards and use the colours and recycled materials in the most imaginative ways; the windows are an opportunity to redesign and interpret paintings and/or images to which they will give a new meaning and a new interpretation.

- Phase D is the final phase dedicated to the exposure, comment and judgment on the experience. The works are hung on the walls or placed on the ground in such a way as to be
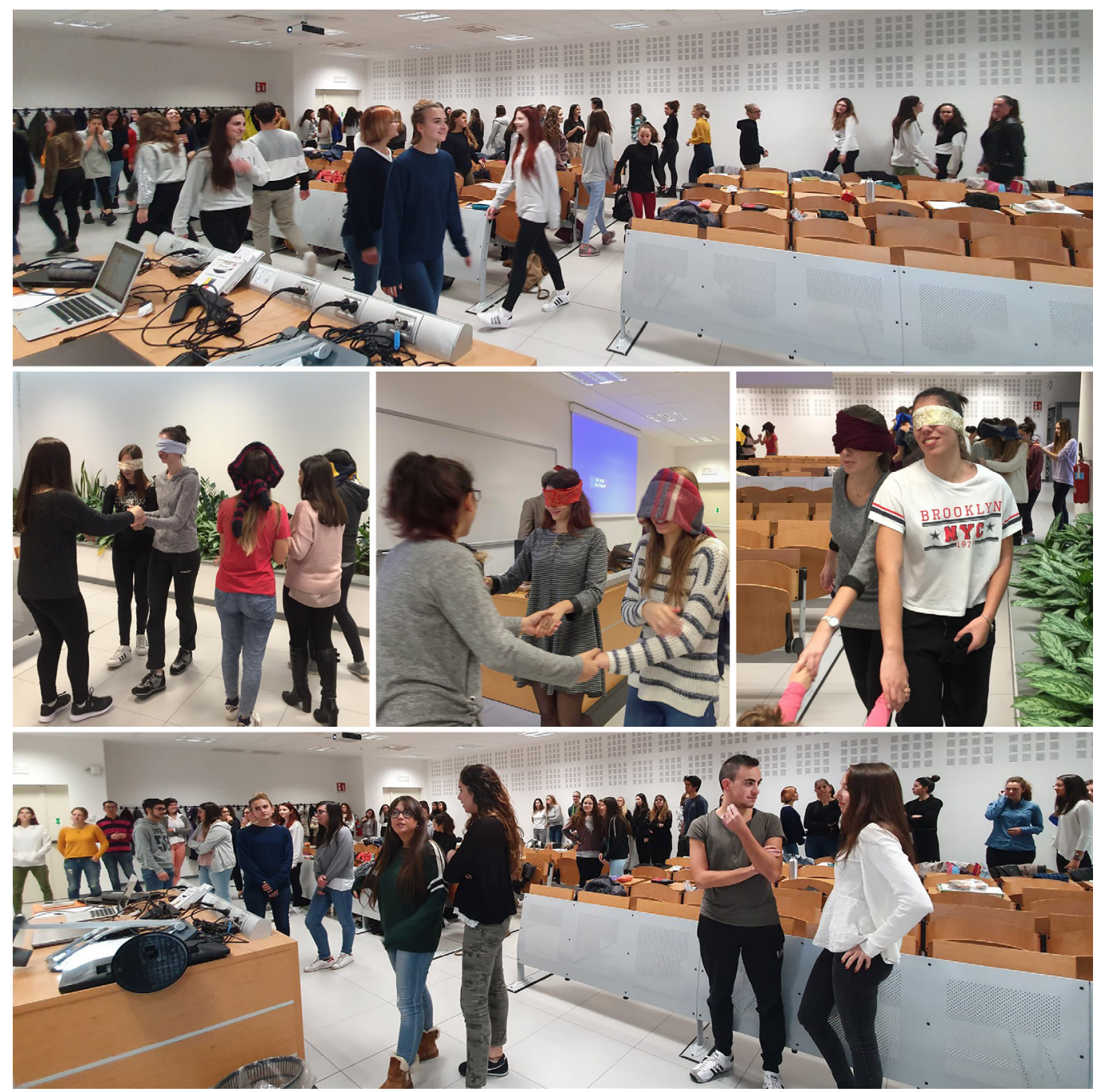
admired by the class; a museum gallery to allow children a reflection based on the comparison of their work with the work of others. Moving next to the works it is possible to leave written comments, suggestions and possibly criticisms as long as motivated. The debate will begin with these 'judgments' used by the teacher to facilitate the discussion: the 'masters' are asked to tell their colleagues allowed their considerations. An 'on' phase of exchange of opinions to reflect on the path, take possession of it, and rethink it reconditioned based on one's desire for improvement. A summary and the teacher's greetings will end the debate suddenly in order not to lose interest in the debate; an 'unexpected' closure will leave 'a bitter taste in the students' who, moving away from the classroom, will continue to fuel the conversation between them.

The evaluation system (the portfolio, the multimedia product and the educational project): the attendance of the workshops and participation in group work ensure that the exam is passed. In the meantime, the student, following the teacher's training path, acquires the necessary skills to achieve the required objectives. The vote is based on commitment and progress, assessed from time to time in the classroom, rather than on the quality of the work. Design is unique and personal, incomparable and immeasurable; it is not possible to judge it, only by attributing it a 'number' because this imposes a ranking of merit, exactly the opposite of what the course wants to teach. There is no more beautiful design because each design is as splendid as all the others, provided it is done with commitment and with the heart.
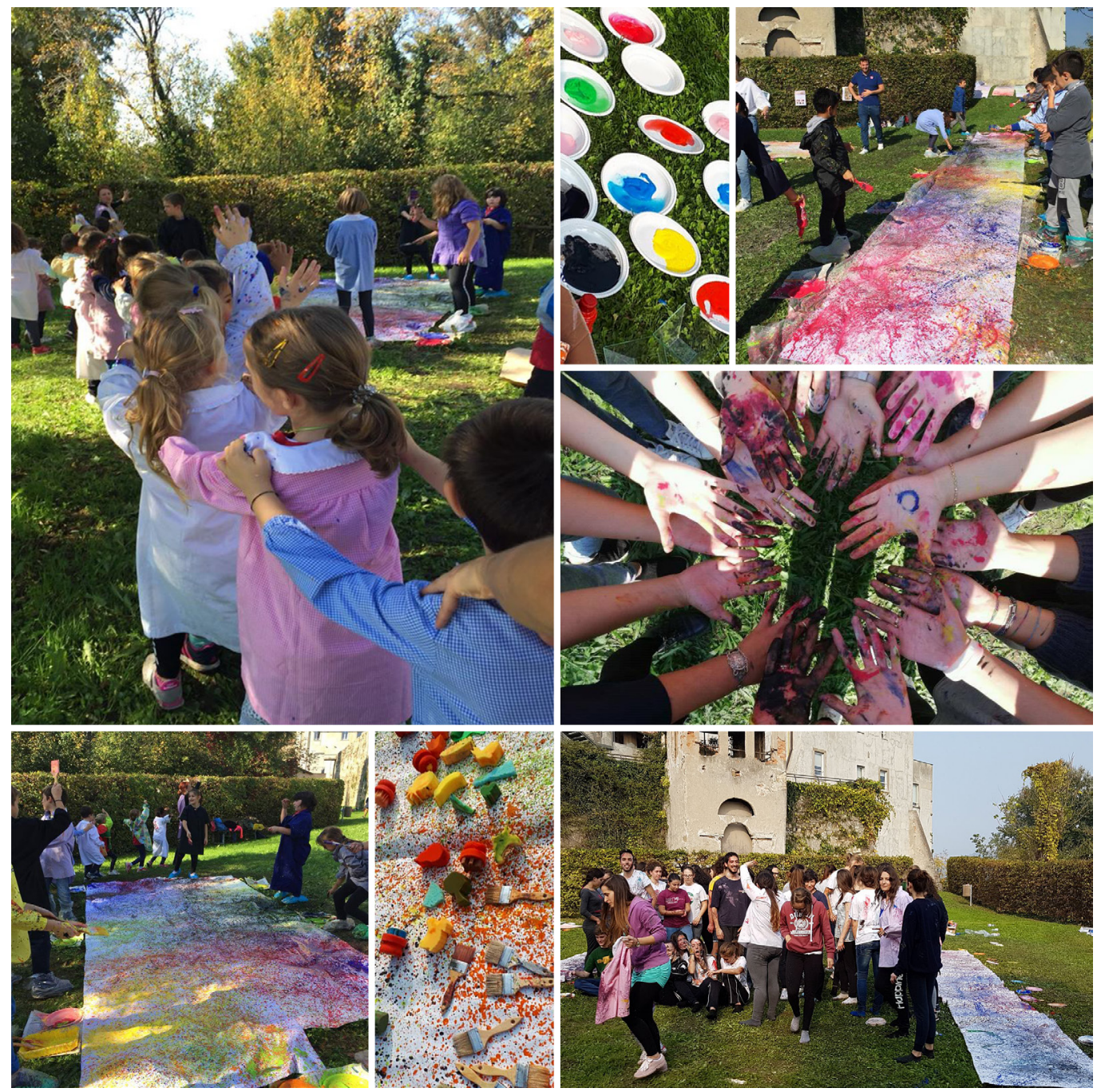
Fig. 6. The workshop "l and my mask": after creating their masks, the students animated them within a short theatrical performance open to the public.
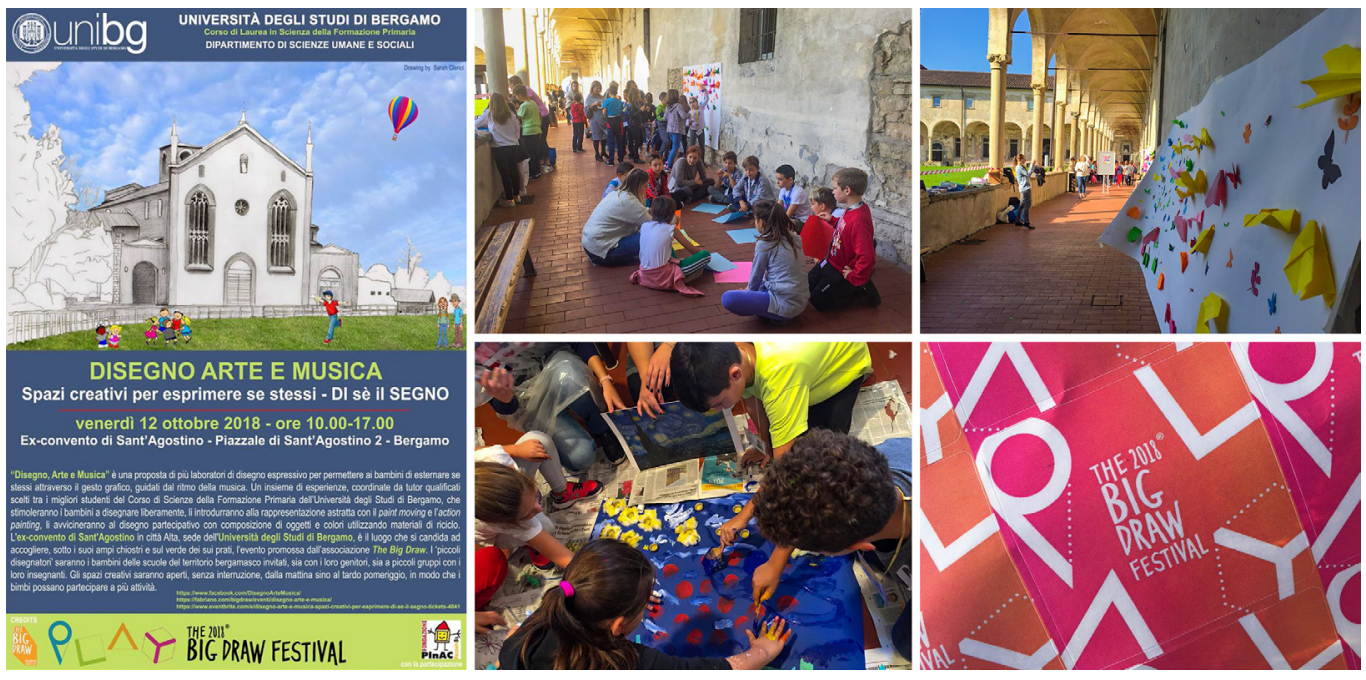

Students are therefore required to narrate their experience in a personal way through a portfolio and a multimedia product (a cartoon, a video, a short film), as well as to draft an educational project.

The portfolio is a relationship in which the candidate presents himself, illustrating his interests, his expectations, talking about the reasons that led him to want to 'become a master'. The boys describe themselves both through their photograph (like the Facebook images that show the person and enhance their character), and through an image that speaks of themselves: a photograph, a drawing, a work of art, designed to communicate the world in which they identify and recognize. The portfolio contains the collection of works and for each work a title is required and the justification of the choice, explaining what we wanted to communicate, why we realized it, what we thought of while composing it, the choice of technique and tools. After realizing the creation, it is very important to research the theoretical notions and conceptual contents within the recommended textbooks, as well as to comment on them critically.

The multimedia product is a movie, limited to a maximum of a few minutes, in which the student has to narrate his path; the results are among the most particular and unpredictable, from the creation of simple image sequences to real costume films based on set design and dialogues. The Drawing manifests within the other arts, such as dance or theatre. The
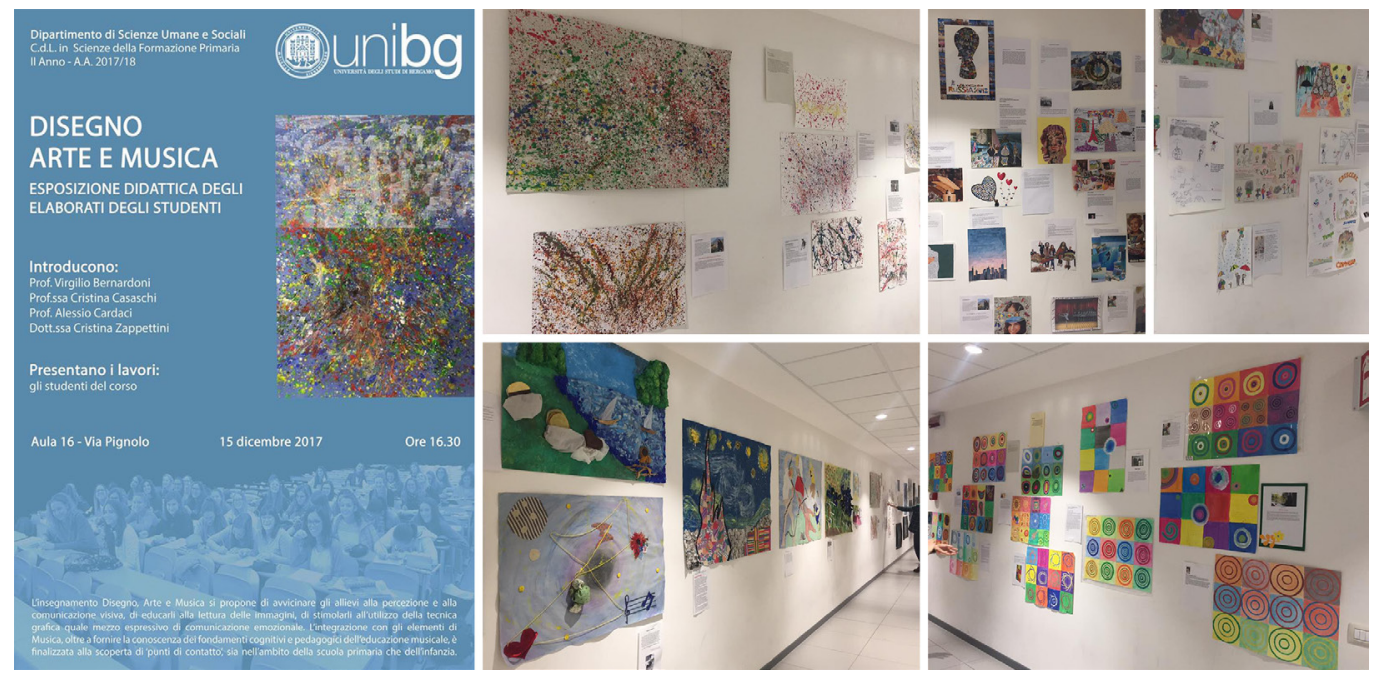

Fig. 7. The Facebook page: students' multimedia products are disseminated online, also to allow the and stimulate new ideas. 
Fig. 8. Multimedia products: an example of a cartoon that describes the student's trainin path.
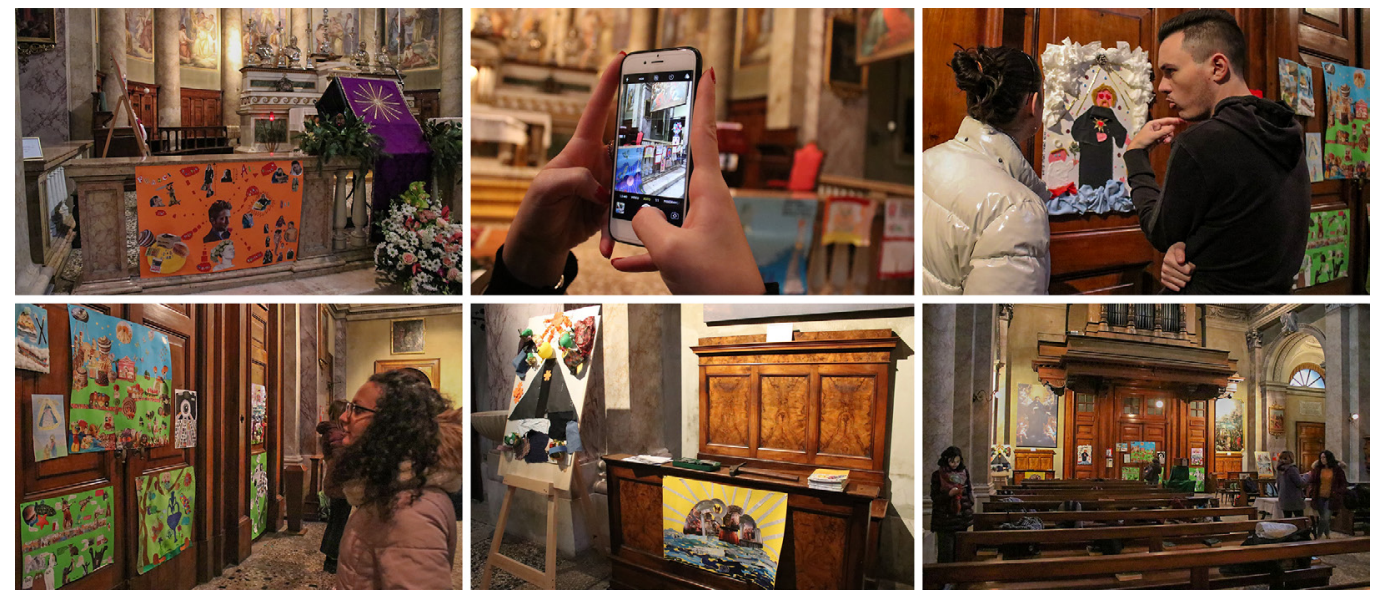

boys are stimulated to create a particular product because they are aware of the fact that everything they create will be published online both on a dedicated YouTube channel (https://www.youtube.com/channel/UCAWhap72WUDDK2wHroraHiw) and through the Facebook page (https://www.facebook.com/DisegnoArteMusica/) of the course. A challenge that is established among students to acquire more likes for their products and that allows the dissemination and content of the course to a large and varied audience.

The educational project was born from the observation of students within schools thanks to the internship path. The children, assisting as spectators in an artistic laboratory, are asked to fill in a form in which to indicate the purpose of the project, report the activity with the explanatory narration of the various work phases and any additions with other disciplines,

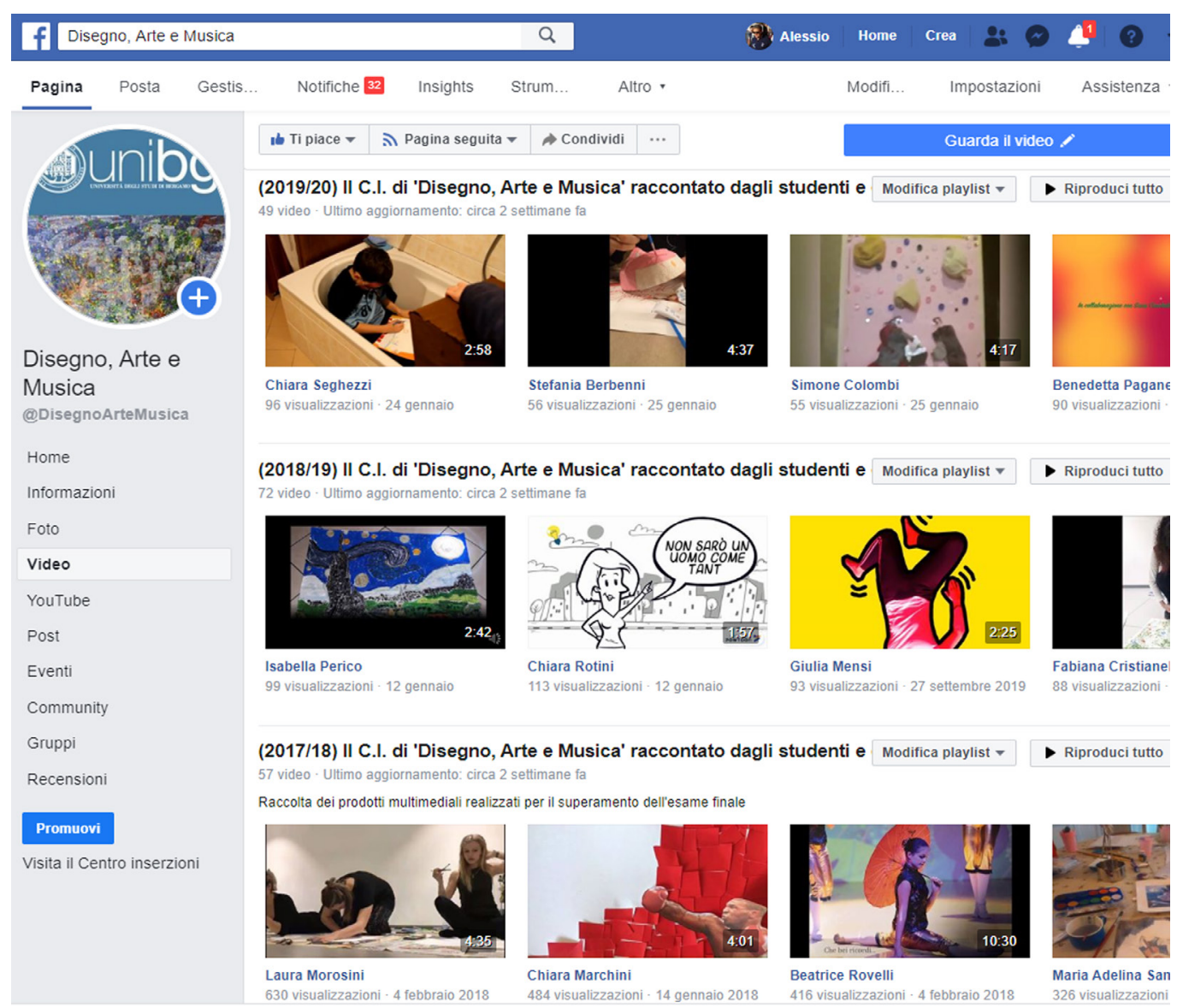


Fig. 10. The Big Draw: the festival offers students plement their educationa projects; schools and families are invited to participate in workshops designed, managed and organized by students.

Fig. I I. The exhibition of the works: the Church of Sant'Andrea Apostolo transformed into a mu-
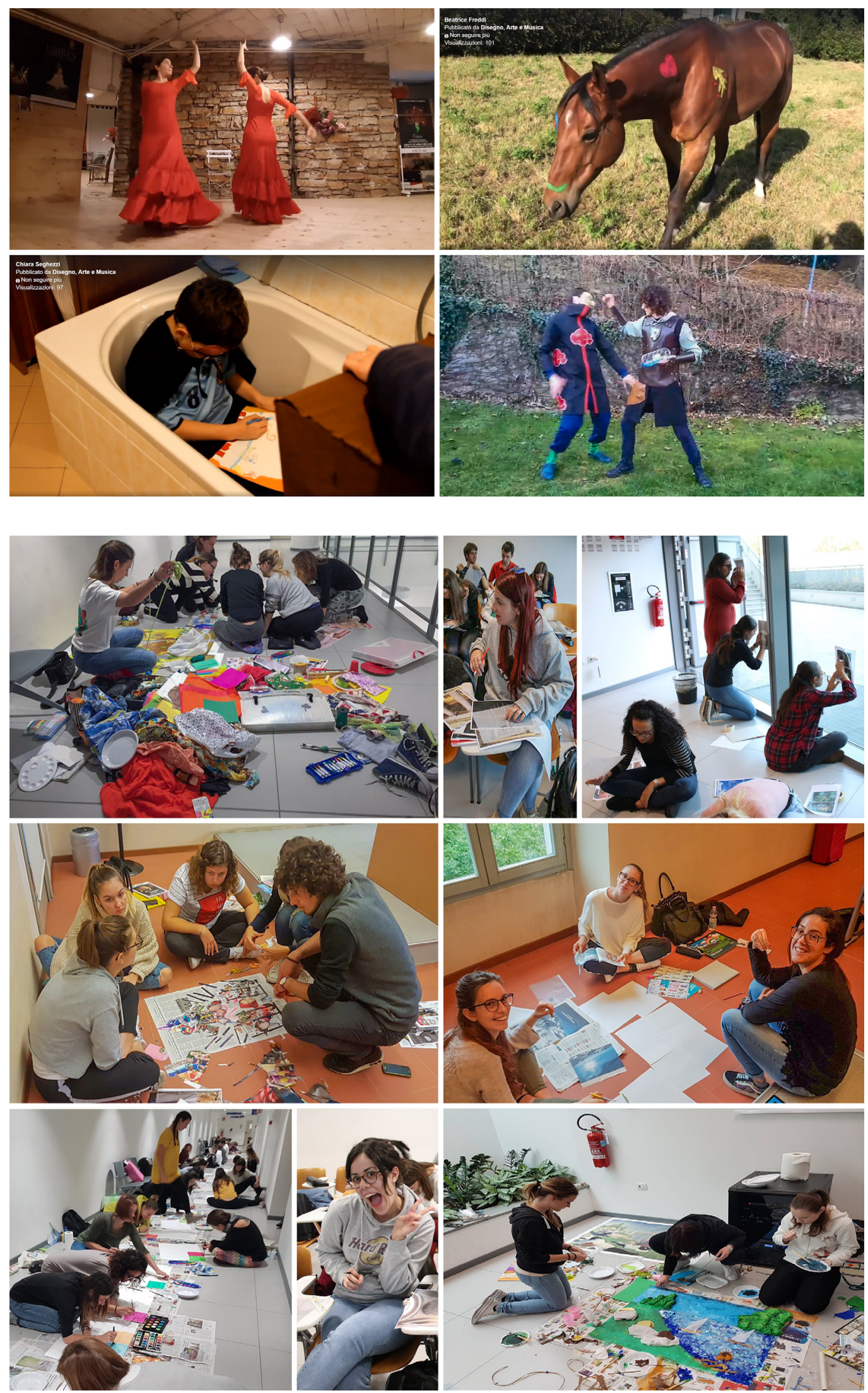
seum of students' works. 
indicate the teaching methodologies and materials used, describe the spaces and fittings; they are also called to check whether the training and design contents follow the national indications of the MIUR and to express a final judgment on the merits. On these bases the boys are therefore called to invent their own business, designing it as if it were their own laboratory. The project is drawn up starting from a title, to then be developed according to the identification data, the training contents and the description of the phases, the objectives and goals to be achieved, places of development and techniques to be adopted. A part of these projects is implemented thanks to the opportunity offered by The Big Draw festival, a space that is repeated every year and in which the university opens up to the city and invites schools and families to participate in totally designed, managed experiences. and organized by students; their first step towards becoming educators and 'putting into practise' what they learned.

\section{Conclusion}

The teaching of Drawing within the Primary Education Science courses is very varied and based on the personal interpretation of the training path by the teacher. Although the ministerial indications identify the contents of the teaching, these are very generic and not very
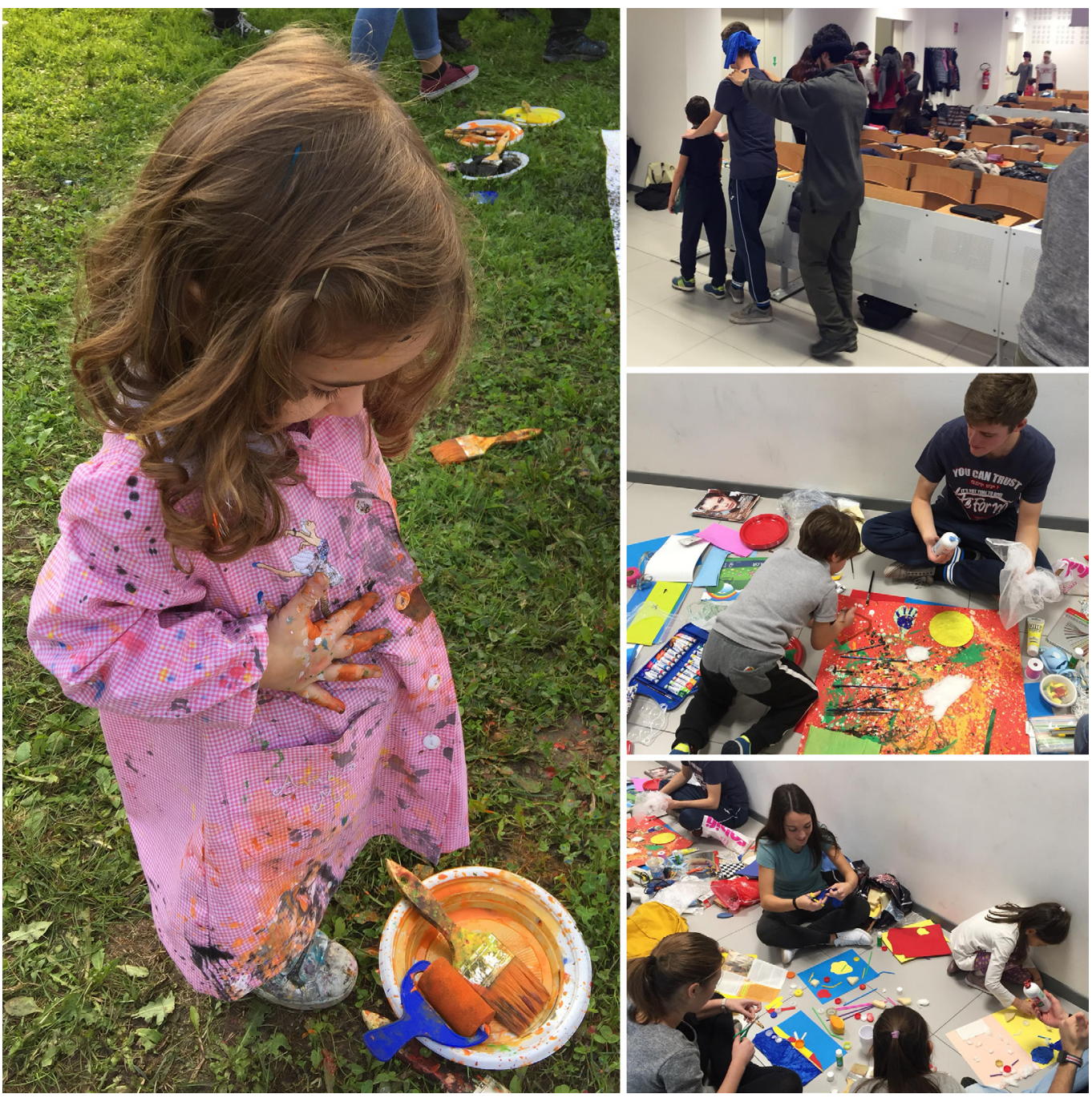
descriptive of the teaching methods and techniques that should be adopted. Our disciplinary sector has attempted, in recent years, to be aware of the various experiences on the national territory, by encouraging the organization of numerous conferences and seminars on the topic; they produced a rich exchange between the teachers and started a debate on the future of this particular declination of the discipline. Alas, the 'official' directives and a complete summary framework are still missing today, as well as a 'manual' and a didactic bibliography of reference, which we hope will be reached (perhaps following a major national congress) to enhance and not disperse the wealth of skills gained by the 'pioneers' of children's drawing [I].

\section{Notes}

[I] A sincere thanks to prof. Giuseppe Bertagna, coordinator of the Bachelor of Science in Primary Education at the University of Bergamo, for the trust placed in me and for the willingness to share my ideas and encourage my teaching choices. A special thanks to prof.Virgilio Bernardoni, professor of the Music module, and to Dr Cristina Zappettini, exerciser of the Drawing and Art module, for the fundamental support - based on a relationship of esteem and collaboration - in the joint teaching activities. Thanks to colleagues from the Human and Social Sciences department of my university for the continuous exchange of ideas and opinions; their advice and suggestions helped to build the teaching of the course.

\section{References}

Appiano Ave (2008). Comunicazione visiva: apparenza, realtà, rappresentazione. Milano: Utet.

Carluccio Carolina (2004). Educazione all'immagine. Napoli: Cues.

Carluccio Carolina (2008). Disegno arte immagine. Napoli: Cues.

González Álvarez Sandra, López Bahut María Emma (2017). La Ciudad del mañana. A Coruña: PØSTarquitectos COAG.

Hachen Massimo (2007). Scienza della visione: spazio e gestalt, design e comunicazione. Milano: Apogeo.

Luigini Alessandro, Panciroli Chiara (20 I8). Ambienti digitali per l'educazione all'arte e al patrimonio. Milano: Editore FrancoAngeli.

Pallasmaa Juhani (2005). The eyes of the skin: architecture and the senses. Chichester:Wiley-Academy.

Panciroli Chiara (2012). Arti visive nella didattica.Verona: QuiEdit Edizioni.

Tonucci Francesco (2005). La città dei bambini: un modo nuovo di pensare la città. Roma-Bari: Laterza.

Van Eyck Aldo (2008). The Child. the City. and the Artist. Amsterdam: Sun Publishers.

Author

Alessio Cardaci, University of Bergamo, alessio.cardaci@unibg.it

To cite this chapter: Cardaci Alessio (2020). II disegno per l'infanzia: approcci interdisciplinari per una nuova forma/The drawing for children: interdisciplinary approaches to a new form of education. In Arena A., Arena M., Brandolino R.G., Colistra D., Ginex G., Mediati D., Nucifora S. Raffa P. (a cura di). Connettere. Un disegno per annodare e tessere. Atti del $42^{\circ}$ Convegno Internazionale dei Docenti delle Discipline della Rappresentazione/Connecting. Drawing for weaving relationships. Proceedings of the 42 th International Conference of Representation Disciplines Teachers. Milano: FrancoAngeli, pp. $216-237$. 